DOUGLAS W. ELMENDORF

Department of the Treasury

\author{
JEFFREY B. LIEBMAN \\ Harvard University
}

\title{
Social Security Reform and National Saving in an Era of Budget Surpluses
}

THE UNEXPECTED EMERGENCE of federal budget surpluses during the late 1990 s, combined with official projections that these surpluses will continue for decades to come, has significantly altered fiscal policymaking. Congressional and administration budget proposals now aim to balance the budget exclusive of Social Security, or exclusive of Social Security and Medicare, rather than on an overall, or unified, basis. Some proposals state the goal of paying off the entire stock of federal debt held by the public within a decade and a half. This fiscal bounty has also altered the likely avenues for Social Security and Medicare reform. Traditional options for ensuring the programs' financial stability-benefit cuts and tax increases-have largely given way to new options focused on using the expected surpluses to prefund future obligations.

The future obligations of Social Security and Medicare under current law are large. The projected aging of the population and rising health care spending imply that federal outlays on these programs will nearly double as a share of GDP over the next seventy-five years, from 6.3 percent in

We formed our understanding of the issues discussed in this paper through innumerable conversations with David Wilcox, Stephen Goss, and other members of the Clinton administration's Social Security reform technical working group. We are grateful for comments from Alan Auerbach, Martin Feldstein, William Gale, James Hines, James Horney, Peter Orszag, James Poterba, Matthew Shapiro, David Skilling, Steve Zeldes, and other participants in the Brookings Panel conference, the Harvard Macroeconomics Seminar, and the National Bureau of Economic Research's Summer Institute Social Security Working Group. The views expressed are entirely our own and not necessarily those of the Treasury Department or any other government agency. Jeffrey Liebman is grateful to the National Instutute on Aging for financial support. 
2000 to 12.2 percent in $2075 .{ }^{1}$ Increased federal spending on Medicaid, which pays for long-term care for low-income seniors, will accentuate this jump. From the perspective of the programs, prefunding these obligations requires a buildup of assets that can be redeemed to pay future benefits. From the perspective of the nation, however, such programmatic prefunding does not necessarily imply that the obligations have been prefunded in an economically meaningful sense. For example, Congress could simply legislate that $\$ 3$ trillion of additional government bonds be placed in the Social Security trust fund immediately. This action would nearly eliminate Social Security's seventy-five-year actuarial imbalance but would, by itself, have no direct economic effects.

Economic prefunding of Social Security and Medicare requires incremental national saving, which is the only way to increase future resources. In this paper we estimate the effect on national saving of a range of Social Security reform plans designed to capture and contrast the main features of existing proposals. The plans we examine specify the income and outlays of - and thus saving within - the Social Security trust fund and any new individual retirement saving accounts that the plans would create. Yet national saving also includes the saving of the non-Social Security part of the federal budget and the non-individual accounts part of the private sector. Hence the overall impact of Social Security reform depends crucially on the response of these other sectors. Our analysis focuses on these responses. We mostly leave aside other critical issues for Social Security reform such as the distribution of benefits, the allocation of risk, and administrative costs, important though these are.

We begin by reviewing the dramatic recent improvement in the federal budget and then discuss the appropriate roles of national saving and programmatic prefunding in response to population aging. Next we explore the relationship of Social Security to the rest of the federal budget, with an emphasis on alternative characterizations of the political economy of budget policy. Then we present our methodology for estimating the effect of Social Security reform on national saving and apply this methodology to a representative set of reform proposals.

Our analysis yields four primary conclusions about the effect of Social Security reform on national saving. First, budget policy matters: some 
elements of reform raise saving if the political process tends to balance the budget excluding Social Security but have no effect on saving if the political process tends to balance the unified budget. In contrast, other elements raise saving only if the political process tends to balance the unified budget. Second, dissimilar plans can have similar effects on capital accumulation, in part because the plans pay out similar total retirement benefits (although often with a different division between traditional benefits and payouts from individual accounts) and in part because responses elsewhere in the budget offset any differences. Third, if policymakers aim to balance the budget excluding Social Security, then all reforms that generate programmatic prefunding-including benefit cuts, payroll tax increases, individual accounts funded from general revenue, and transfers to the Social Security trust fund-raise national saving by a corresponding amount. However, in this case diverting Social Security payroll tax revenue to individual accounts does not raise national saving. Fourth, if policymakers instead aim to balance the unified budget, then the only way that reform can boost national saving is to move money out of the government by funding individual accounts.

\section{The Emergence of Federal Budget Surpluses}

Between the mid-1980s and the early 1990s, persistent efforts to balance the federal budget were overwhelmed by large increases in health spending and by the 1990-91 recession. The result was a unified deficit in 1992 that was nearly as large relative to GDP as the deficits of the mid1980s. Between 1992 and 2000, in contrast, the unified budget balance improved by 7 percent of GDP, from a deficit of 4.7 percent of GDP to a surplus of 2.4 percent. $^{2}$ Table 1 shows that this improvement consists of a significant increase in revenue and a nearly equal decrease in noninterest outlays, both as shares of GDP, together with the resulting impact on interest payments. Debt held by the public fell to 35 percent of GDP in 2000, down from 49 percent just four years ago.

This dramatic turnaround in the fiscal picture stems partly from legislative actions and partly from favorable changes in economic conditions

2. Unless otherwise noted, the data in this section are taken from Office of Management and Budget (2000a) and U.S. Treasury Department (2000). 
Table 1. Selected Federal Government Receipts and Outlays, 1986-2000

Percent of GDP

\begin{tabular}{|c|c|c|c|c|c|c|c|}
\hline \multirow[b]{3}{*}{$\begin{array}{l}\text { Fiscal } \\
\text { year }\end{array}$} & \multicolumn{2}{|c|}{ Receipts } & \multirow{2}{*}{\multicolumn{3}{|c|}{ Noninterest outlays }} & \multirow{3}{*}{$\begin{array}{c}\text { Unified } \\
\text { budget } \\
\text { balance }\end{array}$} & \multirow{3}{*}{$\begin{array}{c}\text { Debt } \\
\text { held by } \\
\text { public }\end{array}$} \\
\hline & \multirow{2}{*}{$\begin{array}{l}\text { Individual } \\
\text { income } \\
\text { taxes }\end{array}$} & \multirow[b]{2}{*}{ Total } & & & & & \\
\hline & & & $\begin{array}{l}\text { Defense } \\
\text { spending }\end{array}$ & $\begin{array}{l}\text { Entitlement } \\
\text { spending }^{\mathrm{a}}\end{array}$ & Total & & \\
\hline 1986 & 7.9 & 17.5 & 6.2 & 10.2 & 19.4 & -5.0 & 39.6 \\
\hline 1987 & 8.4 & 18.4 & 6.1 & 10.0 & 18.6 & -3.2 & 40.6 \\
\hline 1988 & 8.0 & 18.1 & 5.8 & 9.8 & 18.2 & -3.1 & 40.9 \\
\hline 1989 & 8.2 & 18.3 & 5.6 & 9.8 & 18.1 & -2.8 & 40.5 \\
\hline 1990 & 8.1 & 18.0 & 5.2 & 10.5 & 18.6 & -3.9 & 42.0 \\
\hline 1991 & 7.9 & 17.8 & 5.4 & 10.7 & 19.0 & -4.5 & 45.4 \\
\hline 1992 & 7.7 & 17.5 & 4.9 & 11.0 & 19.0 & -4.7 & 48.2 \\
\hline 1993 & 7.8 & 17.6 & 4.5 & 10.8 & 18.5 & -3.9 & 49.5 \\
\hline 1994 & 7.8 & 18.1 & 4.1 & 10.8 & 18.1 & -2.9 & 49.4 \\
\hline 1995 & 8.1 & 18.5 & 3.7 & 10.7 & 17.5 & -2.2 & 49.2 \\
\hline 1996 & 8.5 & 18.9 & 3.5 & 10.7 & 17.2 & -1.4 & 48.5 \\
\hline 1997 & 9.0 & 19.3 & 3.3 & 10.5 & 16.6 & -0.3 & 46.1 \\
\hline 1998 & 9.6 & 19.9 & 3.1 & 10.5 & 16.3 & 0.8 & 43.1 \\
\hline 1999 & 9.6 & 20.0 & 3.0 & 10.3 & 16.2 & 1.4 & 39.9 \\
\hline 2000 & 10.2 & 20.6 & 3.0 & 10.2 & 15.9 & 2.4 & 34.7 \\
\hline
\end{tabular}

Source: Office of Management and Budget, Historical Tables, Budget of the United States Government, Fiscal Year 2001, February 2000; U.S. Treasury Department, Monthly Treasury Statement, September 2000.

a. Total mandatory programmatic spending from Historical Tables.

and in so-called technical factors. ${ }^{3}$ Tax revenue increased as a share of GDP in part because of tax increases legislated in 1993 but also, more important, because of an increase in taxable income relative to GDP, an increase in the share of income received by people in the highest tax brackets, and a surge in capital gains from the booming stock market. ${ }^{4}$ In particular, individual income taxes rose from 8.1 percent of GDP in 1995 to more than 10 percent in 2000, even though no significant tax increases were enacted between those years. Noninterest spending declined as a share of GDP in large part because defense spending was virtually unchanged in nominal dollars and thus fell sharply relative to GDP, and because entitlement spending dipped as a share of GDP. The most dramatic change in entitlement spending relative to the previous eight years

3. "Technical factors" is a residual category that captures changes in tax receipts and expenditures that are due neither to policy nor to the state of the overall economy. Examples include the distribution of income and growth in the relative cost of medical care.

4. Congressional Budget Office (2000). 
occurred in Medicare and Medicaid: a 140 percent jump in nominal spending between 1984 and 1992 was followed by a percentage increase only half that size between 1992 and 2000.

The future prospects for the federal budget have also improved dramatically in recent years, according to both the Office of Management and Budget (OMB) and the Congressional Budget Office (CBO). The OMB now projects that the unified budget surpluses between 2001 and 2010 will total $\$ 4.2$ trillion absent any changes in policy; the same agency projected only $\$ 1.3$ trillion in cumulative surpluses immediately following passage of the 1997 Balanced Budget Act. ${ }^{5}$ The long-run budget picture is also far brighter, as figure 1 shows. In early 1993 the OMB projected that the unified budget deficit would exceed 10 percent of GDP by 2010 and worsen rapidly thereafter; by early 2000 the agency was projecting budget surpluses for the next half century. ${ }^{6}$ The $\mathrm{CBO}$ summarizes its own long-run projections in terms of an estimated "fiscal gap," which is the immediate, permanent tax increase or spending decrease needed to keep public debt below 50 percent of GDP for the next seventy-five years. In May 1996 this gap was 5.4 percent of GDP; by December 1999 the gap was only 0.5 percent of GDP. ${ }^{7}$

Of course, these numbers are forecasts; actual budget surpluses could be substantially smaller or larger, even under unchanged policies. The unexpected improvement in the budget over the past several years-and the sharp deterioration in the early 1990s-provide little reassurance about our ability to predict budget outcomes. Indeed, the OMB, the CBO, and outside analysts regularly discuss many reasons why current projections might not be realized. For example, Alan Auerbach and William Gale argue that "current policy" is better described by holding discretionary spending constant as a share of GDP rather than constant in real terms, as

5. This increase actually understates the favorable economic and technical revisions, because the current projections hold discretionary spending constant over time in real terms whereas the September 1997 projections assumed almost \$1 trillion in real discretionary cuts. We are grateful to John Kitchen for performing these calculations, which include estimates of data that were not reported by the OMB.

6. The 1993 and 1997 projections in figure 1 refer to a baseline of no policy changes, predating the important budget legislation of those years. The 2000 projections refer to the administration's policy proposals (which would reduce the budget balance relative to current law) and predate the substantial upward revision to the ten-year surplus in June.

7. CBO (1997a, 1999). 
Figure 1. Projections of Unified Budget Balance, 1990-2070

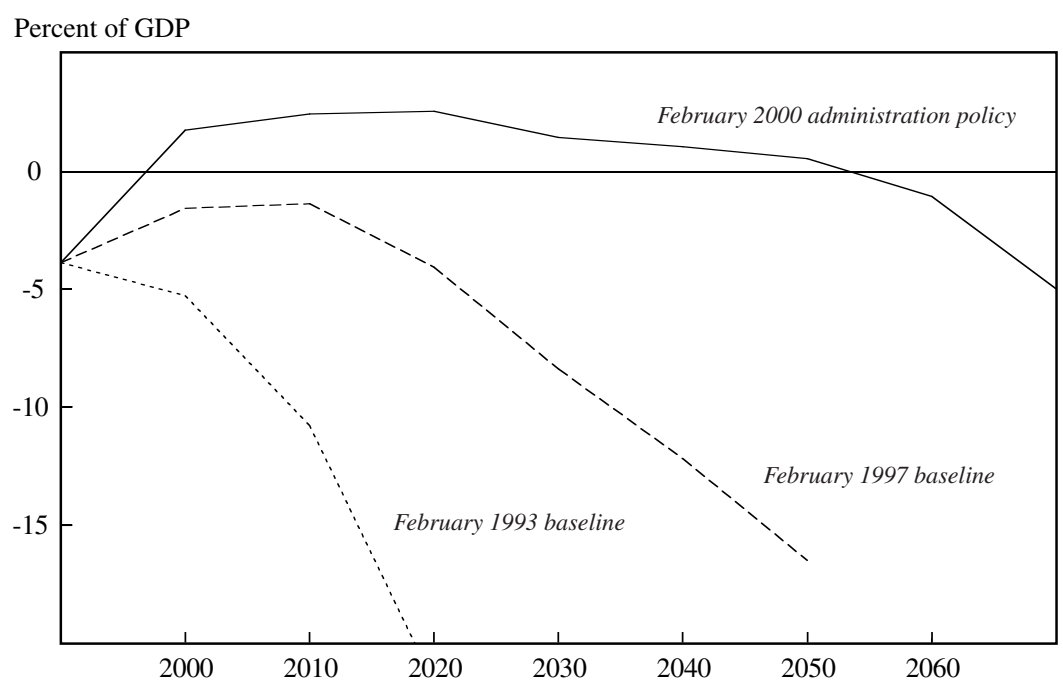

Sources: Office of Management and Budget, Analytical Perspectives, Budget of the United States Government, fiscal years 1998 and 2001 (February 1997 and February 2000), and unpublished OMB data.

in the OMB's long-run projections. Auerbach and Gale estimate that this change widens the fiscal gap by roughly 1 percent of GDP. ${ }^{8}$ The CBO estimates that the fiscal gap would increase by about 1 percent of GDP if tax receipts declined to their average share of GDP before the surge of the late 1990s. ${ }^{9}$ Moreover, budget analysts face important uncertainty about long-term productivity growth and increases in health spending. In sum, there is substantial doubt about how rosy the current budget outlook really is, but little doubt that it has improved dramatically of late and that the improvement has changed the terms of the public debate about Social Security reform.

\section{Population Aging, National Saving, and Prefunding of Retirement Benefits}

Social Security benefits and administrative costs now equal 10.3 percent of payroll (4.2 percent of GDP), and the retirement of the baby-boom

8. Auerbach and Gale (2000).

9. CBO (1999). 
generation is projected to push that share to 17.4 percent of payroll by 2030. Moreover, because the aging of the population is expected to be permanent, not temporary, this share is projected to reach 19.5 percent of payroll in 2075. Since these benefits generally correspond to consumption by persons who will not be working, they represent a significant economic burden for the nation. The projected increase in benefits also represents a significant burden for the Social Security program, because dedicated income from the payroll tax and the taxation of benefits is projected to remain around 13 percent of payroll through 2075. In this section we examine the appropriate response to population aging by the nation and by the program itself.

\section{The Central Role of National Saving}

The primary way in which current generations can increase the resources available to future generations-and thus absorb some of the burden of an aging population - is to bequeath the ownership of a larger quantity of physical capital. (We leave aside several related ways to help future generations, including better education and more investment in research and development to augment the stock of technical knowledge.) It is relatively unimportant whether this additional capital is located in the United States or overseas: the future consumption of domestic residents depends on their income, and tomorrow's national income depends primarily on today's national saving, wherever that saving is invested.

Economists generally view the decisions of individuals as revealing their true preferences. However, many economists have concluded that U.S. national saving is too low. One piece of evidence is that the U.S. national saving rate has for some time been lower than that of most other developed countries and is now below its own historical average. Using an explicit welfare function to aggregate the utility of different generations may also suggest that the current capital stock is below its optimal level, although alternative choices for the parameters of that function lead to different conclusions. ${ }^{10}$ In addition, economists have identified some specific reasons why national saving might be lower than is desirable: households may be myopic or have time-inconsistent preferences, ${ }^{11}$ government 
policies may discourage saving through capital income taxes, ${ }^{12}$ and pay-asyou-go retirement programs like Social Security and positive externalities from capital accumulation may make the social return to saving exceed the private return. ${ }^{13}$

An additional, commonly voiced argument for raising national saving is the aging of the population. In a life-cycle model, individuals prepare for their own retirement by saving when they are young, and so it seems natural that a nation should increase its saving in advance of an expected aging of its population. However, David Cutler and others show, as do Elmendorf and Louise Sheiner, that population aging does not establish an unambiguous case for higher saving. ${ }^{14}$ The analogy to individual behavior breaks down because whereas the anticipated withdrawal of one individual from the labor force does not affect his or her expected return to saving, the aging of the U.S. population in the aggregate will likely reduce the return to national saving. In particular, the decline in fertility that is the primary cause of our population aging will reduce labor force growth to nearly zero by 2020; this will increase the capital-labor ratio and thereby lower the marginal product of capital. ${ }^{15}$ Optimal saving is depressed by the lower return, but boosted by the greater demand for future resources. On balance, Elmendorf and Sheiner conclude that projected population aging in the United States does not justify large increases in saving; indeed, some plausible specifications imply that current saving should actually decline slightly in response to population aging.

Regardless of the optimal level of saving, the level of capital accumulation accomplished by Social Security reform reflects the true prefunding of future consumption, and it is nearly a sufficient statistic for what current generations are doing for future generations. It is therefore of primary importance in comparing Social Security reform proposals.

12. Lucas (1990).

13. Feldstein (1974); Romer (1986).

14. Cutler and others (1990); Elmendorf and Sheiner (2000).

15. The marginal product of capital would not fall if the United States were a completely open part of a world capital market in which a fixed interest rate prevailed. However, net capital flows are not that large, and world interest rates will likely decline over time because most other developed countries are aging even more rapidly than the United States. 


\section{Prefunding Social Security}

For sixty years Social Security has been primarily a pay-as-you-go system, but the aging of the U.S. population will require sharp changes in taxes or benefits if the pay-as-you-go approach is to be maintained. Under current projections, achieving balance between the system's revenue and outlays in 2075 would require a one-third cut in benefits or a one-half increase in payroll taxes. Faced with that prospect, it is natural to consider prefunding future benefits by accumulating assets in the Social Security trust fund. ${ }^{16}$ Indeed, the effort has already begun. Social Security reforms in 1977 and 1983 set payroll taxes above contemporaneous benefits, and the trust fund now holds roughly $\$ 1$ trillion in government bonds. Even so, the trust fund is projected to peak in 2024 and be exhausted in 2037, and maintaining solvency for the next seventy-five years (a traditional benchmark) is projected to require an immediate increase in payroll taxes of 1.89 percentage points or an equivalent cut in benefits.

The 1994-1996 Advisory Council on Social Security presented three alternative reform plans that placed important emphasis on additional prefunding and moved two other ideas to the center of the Social Security debate: individual retirement saving accounts and investment in equities. ${ }^{17}$ The emphasis on prefunding has increased even more in the past few years, primarily because of the emergence of large projected budget surpluses. These surpluses offer a new funding source with relatively low political cost: additional revenue can be directed to the Social Security trust fund or to individual accounts without explicitly raising taxes, cutting other spending, or incurring a deficit. (There is, however, a political opportunity cost in the form of taxes not reduced and other spending not increased.) For example, the advisory council's Individual Accounts proposal would have required taxpayers to contribute to new, individual retirement saving accounts in addition to paying the current payroll tax; under current budget projections, these accounts could instead be financed using "excess" general revenue. Reforming Social Security by legislating future benefit cuts or tax increases appears to be especially unappealing to voters when the government already has a significant excess of tax revenue over spending. Indeed, the political willingness to consider Social Security 
reform at a time when the program faces no immediate problems may be due largely to the potential to achieve long-term solvency in a politically less painful way.

Prefunding of benefits brings a number of possible advantages, depending on one's viewpoint. First, dedicating some share of projected budget surpluses to Social Security could help preserve those surpluses when they might otherwise be used for tax cuts or spending increases. That is, if policymakers believe that more national saving is desirable but have difficulty making the case to the public, justifying that saving in terms of strengthening Social Security might generate more popular support. Second, prefunding a rising stream of government outlays would help to smooth tax rates over time and minimize the deadweight loss from future taxation. ${ }^{18}$ In particular, higher tax rates today not only would provide future generations with additional capital, but would also increase the resources within the government sector, reducing the need for high tax rates and large deadweight losses to transfer these resources into the government sector in the future. Third, accumulating assets dedicated to paying Social Security benefits would make it politically less likely that these benefits would be cut in the future. If one is concerned that tomorrow's elderly may ultimately bear too large a share of any required budgetary adjustments, strengthening the commitment to pay current-law benefits is important. Fourth, some advocates believe that people should have greater control over their own retirement savings, and granting such control requires prefunded individual accounts.

Prefunding of benefits also has potential disadvantages, again depending on one's perspective. These disadvantages relate primarily to the locking in of future benefit levels. First, if programmatic prefunding should fail to accomplish a corresponding amount of economic prefunding, the result would be to reinforce the commitment to pay current-law benefits without increasing the resources available to meet that commitment. Such a reform would simply shift future resources toward Social Security beneficiaries and away from other U.S. residents. Second, current-law benefits, even if prefunded through additional national saving, might already be higher than desirable. Some analysts think the government should devote a smaller share of its resources to retirees, and if, as suggested above, population aging will reduce future consumption (relative to the case of no 
demographic change), then protecting current-law benefits for retirees may be especially inappropriate. Indeed, current generations could pass "political capital" to future generations by legislating politically unpopular benefit cuts or tax increases today. Third, preserving flexibility in future benefit levels may be the right response to the tremendous uncertainty about future economic conditions and social priorities. Ronald Lee and Shripad Tuljapurkar estimate that, given uncertainty about future fertility, mortality, productivity growth, and interest rates, the 95 percent confidence interval for the pay-as-you-go Social Security payroll tax rate sufficient to cover benefits in 2070 ranges from 16 percent to 34 percent. ${ }^{19}$

\section{Budget Policy}

The effect of Social Security reform on national saving is the sum of its effects on government saving and private saving. In this section and the next, we explore the effect on government saving, which is complicated by the potential impact of reform on other government taxes and spending (especially in light of the newly emphasized distinction between Social Security and the rest of the government budget). In later sections we analyze how the total capital accumulation accomplished by Social Security reform is altered by household saving responses as well as by changes in revenue from the taxation of capital and in the returns to capital and labor.

\section{Social Security and the Unified Budget}

In 1967 a government commission proposed that all revenue and expenditure of the federal government be included in a unified budget. ${ }^{20} \mathrm{By}$ combining previously separate accounts, this change increased the transparency of the budget and encouraged policymakers to make tax and spending policy in an overall framework rather than in a fragmented way. However, the 1983 Social Security reform officially took the two Social Security trust funds (the Old-Age and Survivors Insurance trust fund and the Disability Insurance trust fund) "off budget." The detailed budget 
tables of both the OMB and the CBO subsequently showed the operations of those funds separately from the "on-budget" activities of the rest of the government. ${ }^{21}$ The on-budget and the off-budget accounts together constitute the unified budget, whose surplus equals government saving. The stock of debt held by the public falls by roughly the amount of the unified surplus (with the small difference stemming from technical factors known as "other means of finance").

Table 2 summarizes the on-budget, off-budget, and unified budget accounts for fiscal years 1976, 1997, and 2000. In 1976 Social Security was nearly in balance as a pay-as-you-go system, and the unified budget deficit was quite close to the deficit in the on-budget account. By 1997 Social Security was running a substantial surplus that was more than offset by a non-Social Security deficit, leading to a small unified deficit. And in 2000 both the off-budget account and the on-budget account recorded surpluses, so that the unified budget was also in surplus.

Between 1967 and 1999 both public attention and the official budget process focused on the unified budget. The underlying fiscal objective was perceived as unified budget balance, at least on average over the business cycle, although in fact deficits were recorded in nearly every year. Thus, as the fiscal outlook improved in the late 1990s, most policymakers viewed the projected unified surpluses as the amounts available for new spending or tax cuts. In the spring and summer of 1999, however, policymakers shifted quite suddenly and dramatically to a different objective, that of balancing the budget excluding Social Security.

This shift occurred in part because of a perception that an on-budget deficit (or, equivalently, a unified surplus smaller than the Social Security surplus) constituted a "raid" on Social Security. In fact, the Social Security trust fund receives special Treasury securities equal to the Social Security surplus regardless of the financial position of the rest of the government. The legitimate concern about the on-budget balance is whether it is undermining the potential role of trust fund accumulation in boosting government and national saving. To the extent that the non-Social Security balance deteriorates when the Social Security bal-

21. The U.S. Postal Service is also off budget, but its annual surplus or deficit is dwarfed by the Social Security surplus, and the Clinton administration and others have recently proposed taking Medicare off budget. However, in this paper we refer only to Social Security as off budget. 
Table 2. Off-Budget, On-Budget, and Unified Budget Accounts, Selected Fiscal Years Billions of dollars

\begin{tabular}{lccc}
\hline $\begin{array}{c}1976 \\
\text { Social Security } \\
\text { balance and on- } \\
\text { budget deficit }\end{array}$ & $\begin{array}{c}1997 \\
\text { Social Security } \\
\text { surplus and on- } \\
\text { budget deficit }\end{array}$ & $\begin{array}{c}2000^{\mathrm{a}} \\
\text { Social Security } \\
\text { surplus and on- } \\
\text { budget surplus }\end{array}$ \\
\hline $\begin{array}{l}\text { Item } \\
\text { Off-budget account }\end{array}$ & & & \\
Social Security) & 68 & 405 & 496 \\
Taxes & -74 & -365 & -407 \\
Benefits & 3 & 41 & 60 \\
Interest & -3 & 81 & 148 \\
Balance & & & 1,479 \\
On-budget account & 232 & 1,187 & $-1,180$ \\
Taxes & -273 & $-1,005$ & -60 \\
Noninterest outlays & -3 & -41 & -220 \\
Interest to Social Security & -27 & -103 & 19 \\
Interest to public & -71 & -22 & 167 \\
Balance & -74 & & \\
Unified budget balance & & & \\
\hline Source: Office of Management and Budget, Historical Tables, Budget of the United States Government, Fiscal Year 2001, \\
February 2000. \\
a. Projected. These numbers are not consistent with the final data for fiscal year 2000 shown in table 1 because a detailed \\
decomposition of the on-budget and off-budget accounts has not been published by the OMB since February 2000.
\end{tabular}

ance improves, the extra trust fund accumulation is a paper transaction with no corresponding impact on national saving. To the extent, however, that this is not true, trust fund accumulation corresponds to an improvement in the government's overall financial position and to additional national saving. ${ }^{22}$

Looking back over the unified deficits and Social Security surpluses of the past twenty years, we can consider the economic impact of trust fund accumulation to date. The excess of payroll taxes over Social Security benefits clearly reduced the unified budget deficit in a mechanical way. At the same time, this reduction made the "deficit problem" somewhat less pressing in the public eye, so that other taxes were probably not raised as

22. Frances Perkins, secretary of labor under President Franklin Roosevelt, apparently understood that building up the Social Security trust fund would have no economic effect if the fund were not separated from the rest of the government budget. She wrote that "Obviously, so long as the Government was operating with a large deficit, any government "contribution' would be merely a book-keeping entry crediting the social insurance fund, rather than actual cash" (Perkins, 1946, p. 296). 
much, nor was other spending cut as much, as would have happened otherwise. On balance, it seems likely that the buildup of the trust fund led to incremental government saving, although less than dollar for dollar because of the resulting changes in the rest of the government budget. ${ }^{23}$

Looking ahead, a fundamental determinant of whether Social Security reform will raise national saving is whether the new consensus to balance the on-budget account will persist. It is noteworthy that the 1983 law taking Social Security off budget-and the reaffirmation of this action in the budget legislation of 1985 and 1990-was not sufficient to redirect public attention to the on-budget balance. ${ }^{24}$ In contrast, a number of state governments have successfully focused their budget deliberations on revenue and outlays excluding employee retirement funds. One threat to the new consensus would be a worsening of the budget outlook that would require spending cuts or tax increases to reach balance in the on-budget account even with the government reporting an overall surplus. Another threat could arise from the continuation of favorable budget trends. Debt held by the public is now roughly $\$ 3.4$ trillion, and the OMB projects that Social Security surpluses will total nearly $\$ 2.5$ trillion over the next twelve years and be running over $\$ 300$ billion per year at the end of that period..$^{25}$ Therefore, if the non-Social Security budget is balanced on average, debt held by the public could be entirely paid off by 2012. After that point, balancing the on-budget account would require the government to purchase private assets in an amount equal to the Social Security surpluses. This switch from paying off the national debt to building up a "national asset" could significantly alter the political context of budget policy.

\section{Medicare and the Budget}

Last summer the Clinton administration set forth a budget plan that would take Medicare Part A off budget, like Social Security, and balance the government's remaining taxes and outlays. ${ }^{26}$ Medicare Part A provides insurance for hospitalization; it is financed through the Hospital

23. Aaron and Reischauer (1998) argue that trust fund accumulation may understate incremental capital because the return earned by the trust fund on the government bonds it holds is less than the marginal product of capital.

24. Koitz (1998) reviews the history of Social Security's budget status.

25. OMB (2000b).

26. OMB (2000b). 
Insurance trust fund, which receives income from dedicated revenue streams (primarily the payroll tax) and, like the Social Security trust funds, is expected to accumulate sizable balances in coming years. ${ }^{27}$

The economic and budget issues regarding the prefunding of future Medicare benefits are quite similar to those for Social Security. ${ }^{28} \mathrm{~A}$ growing balance in the Part A trust fund will correspond to economic prefunding only if Part A surpluses are not part of the budget that the political process tries to balance. Consider, for example, a hypothetical reduction in hospital reimbursement rates (analogous to the cuts in Social Security benefits that we consider later). The decline in outlays would result in a larger Part A surplus and additional bonds in the Part A trust fund. If Part A were taken off budget, this incremental surplus would raise government and national saving. However, if Part A remained on budget, lower Part A outlays might create the perception that more money is available for tax cuts and new spending, and the policy would extend the solvency of the Part A trust fund without raising saving or improving the government's overall fiscal condition. Moreover, this analysis applies equally to reductions in outlays arising from technical factors such as lower treatment intensity.

The idea of taking Medicare off budget has received much less attention over the years than the idea of taking Social Security off budget, presumably because Part A surpluses have been very small. However, legislative action and favorable economic and technical changes have improved the outlook for the trust fund substantially in the past seven years: its projected exhaustion date has been pushed back from 1999 in April 1993, to 2012 in April 1998, and 2025 in April 2000. With a trust fund balance over $\$ 150$ billion and projected Part A surpluses of roughly $\$ 400$ billion during

27. Medicare Part B provides insurance for visits to physicians; it is financed through the Supplementary Medical Insurance trust fund, which receives one-quarter of its income from beneficiary premiums and three-quarters from general revenue. Because these amounts are set annually to cover expected costs, this trust fund holds only small working balances; its removal from the budget would have no substantive effect on national saving, and the administration did not propose it.

28. See Feldstein and Samwick (1997) and Feldstein (1999). Some of the same issues also arise regarding the trust funds for retirement benefits for government employees: the Civil Service Retirement Fund and the Military Retirement Fund. Contributions to these trust funds by the relevant agency or employees or by the general fund augment fund balances, which now exceed $\$ 650$ billion. But the contributions also count as offsetting onbudget receipts and thus do not reduce the resources available for other purposes or contribute to incremental government saving. 
the next ten years ${ }^{29}$ substantial prefunding of Medicare benefits is now on the horizon. Whether those surpluses will be off the table in discussions of new spending and tax cuts is a consequential decision for the budget and for national saving.

\section{On-Budget Balance}

The current political consensus essentially sets a two-part objective for fiscal policy: balance the budget excluding retirement programs, and ensure the solvency of retirement programs for the foreseeable future. Although most of this paper is concerned with the positive implications of political economy rules, the normative merits of the current consensus deserve a brief discussion.

The current approach does not represent optimal fiscal policy in the strict sense of the word. Economists have long noted that a zero balance in the unified budget possesses no economic magic, ${ }^{30}$ and balance in the on-budget account combined with projected solvency for the retirement system suffers from many of the same shortcomings. For example, optimal fiscal policy would give some weight to the amount of outstanding government debt, and it would depend on an assessment of the distortions to private saving and the adequacy of that saving. In addition, any attempt to achieve budget balance each year, rather than on average across the business cycle, would undermine the automatic fiscal stabilizers.

Nevertheless, we believe that the current two-part consensus is the best practical framework for fiscal policy. Achieving balance in some budget concept is a salient political objective, and the appropriate budget to balance (on a business-cycle-average basis) is the budget excluding retirement programs, for several reasons. First, this approach encourages forward-looking policymaking in the face of population aging. It is now a truism to remark that current budget surpluses should not be dissipated casually, because future budget demands will be much greater. In this situation, focusing on the surplus remaining after setting aside the resources needed to prefund those future demands gives a more accurate picture of our overall fiscal position. Second, this approach reinforces a long-term focus in policymaking for Social Security. For example, this year's par-

29. OMB (2000b).

30. For example, see Eisner (1986) and Auerbach, Gokhale, and Kotlikoff (1991). 
tial repeal of the retirement earnings test has a short-run cost but a negligible long-run effect on Social Security's financial status; because the annual budget debate now excludes Social Security, the short-run cost was appropriately ignored in the discussion of this repeal. ${ }^{31}$

Third, and most important, balancing the budget excluding Social Security gives economic meaning to accumulations in the Social Security trust fund: additional bonds in the trust fund are then matched dollar for dollar by a reduction in government debt held by the public and additional government saving. The government budget is essentially a cash-flow accounting system, and the political process tends (as already noted) to push the net cash flow of some budget concept toward zero. Therefore, government saving can occur on a consistent basis only outside of whatever budget concept is balanced; trust funds inside that budget concept may have political and programmatic implications but do not have economic ones. ${ }^{32}$

\section{Social Security Reform and the Political Economy of the Budget}

With these budget concepts in hand, we can now analyze the effect of Social Security reform on saving under alternative approaches to setting spending and taxes in the non-Social Security part of the budget. The reform proposals of the past several years involve different combinations of five canonical elements: cuts in Social Security benefits or increases in payroll taxes; transfers of on-budget revenue to the Social Security trust

31. Indeed, a majority of the 1983 Social Security commission favored taking Social Security out of the budget partly to ensure that reforms were "made only for programmatic reasons, and not for purposes of balancing the budget" (National Commission on Social Security Reform, 1983, p. 2-24). A partly countervailing argument is that small changes in Social Security may have too little impact on seventy-five-year solvency to receive as much attention as they would in the annual budget process. Thus the minority on the commission who opposed taking Social Security off budget deemed it "important to ensure that the financial condition of the Social Security program be constantly visible to the Congress and the public" (National Commission on Social Security Reform, 1983, p. 2-25).

32. It is sometimes said that an on-budget focus will lead to less saving than would a unified budget focus when Social Security begins to run deficits. This argument ignores the second part of the current consensus by assuming that no actions will be taken in the next twenty-five years to extend Social Security's solvency. Moreover, the goal of focusing on the on-budget account is not to raise saving arbitrarily but to match trust fund accumulations with saving; if future demographic changes justify a reduction in the trust fund, the resulting decline in saving need not be regretted. 
fund; the purchase of equities by the trust fund; contributions of on-budget revenue to individual accounts ("add-on" accounts); and contributions of Social Security revenue to individual accounts ("carve-out" accounts). We assume that withdrawals from individual accounts will be taxed just as Social Security benefits are, with most of the revenue accruing to Social Security. ${ }^{33}$ In addition, some reform proposals "claw back" (that is, tax) a large share of these withdrawals and direct those revenues to Social Security to help finance traditional benefits.

\section{National Saving and Its Composition}

The effect of Social Security reform on national saving is the sum of its effects on government saving, personal saving, and business saving. We divide government saving into the Social Security surplus and the onbudget surplus, and we assume that the surpluses of state and local governments are unaffected by reform. We divide personal saving into saving within individual accounts and household saving. Saving in each of these four sectors equals the return on that sector's stock of net assets, plus other income, less other outgo. The return on net assets includes (where relevant) bond coupon payments, equity dividends, and capital gains on equities. We do not allow for revaluations of existing capital (that is, for changes in Tobin's $q$ ), and so these capital gains reflect appreciation owing to retained earnings and therefore correspond to business saving. Thus we do not model the business sector explicitly but rather "pierce the corporate veil" and attribute business saving to the other sectors. Saving in each sector can be defined as follows:

Social Security saving (Social Security surplus) = Social Security taxes (SST)

- Social Security benefits $(S S B)$

+ transfers from the on-budget account to Social Security (TRANS)

- Social Security contributions to individual accounts (SSCON)

33. In 1999 taxation of Social Security benefits reaped $\$ 12$ billion for the two Social Security trust funds and $\$ 7$ billion for the Hospital Insurance trust fund (Board of Trustees of the Federal Old-Age and Survivors and Disability Insurance Trust Funds, 2000; Board of Trustees of the Federal Hospital Insurance Fund, 2000). Our saving estimates include the flow of revenue to the Social Security trust funds. 
+ clawbacks and taxes on withdrawals from individual accounts $(C L A W)$

+ the return on net assets of the Social Security trust fund (SSR).

On-budget government saving (on-budget surplus) $=$ non-Social Security taxes $(T)$

- non-Social Security spending excluding interest $(G)$

- transfers from the on-budget account to Social Security (TRANS)

- on-budget contributions to individual accounts $(O B C O N)$

+ the return on net assets in the on-budget account $(O B R)$.

Individual account saving $=$

Social Security contributions to individual accounts (SSCON)

+ on-budget contributions to individual accounts $(O B C O N)$

- withdrawals from individual accounts for consumption (WITH)

- clawbacks and taxes on withdrawals from individual accounts $(C L A W)$

+ the return on net assets in individual accounts (IAR).

Household saving $=$

household saving apart from the return on existing assets $(H S)$

+ the return on household assets $(H R)$.

Because many of these components of saving cancel across sectors, the effect of Social Security reform on national saving can be written as:

$$
\Delta N S=\Delta S S T-\Delta S S B-\Delta W I T H-\Delta G+\Delta T+\Delta H S+\Delta R,
$$

where $N S=$ national saving and $R=S S R+O B R+I A R+H R=$ national income from capital. Changes in on-budget taxes and spending have two sources: changes in capital tax revenue owing to changes in capital accumulation in prior years, and the response of the budget process to Social Security reform. This budget policy response could include changes in both taxes and spending, but we generally refer just to spending for simplicity. To focus on this response in the rest of this section, we leave aside any changes in household saving, capital tax revenue, and the return on incremental saving in previous years. Under these restrictions:

$$
\Delta N S=\Delta S S T-\Delta S S B-\Delta W I T H-\Delta G .
$$




\section{Political Economy Rules}

We study four alternative descriptions of the response of on-budget taxes and spending to budget developments. These "political economy rules" are meant as positive descriptions of how budget policy might respond to Social Security reform, not as prescriptions or as proposals for budget rules to constrain the political process. Although we show that these on-budget responses to Social Security reform can substantially offset the apparent saving effects of some reforms, it is worth noting that freeing up resources for important social purposes apart from Social Security is one plausible goal of reform.

Our alternative political economy rules are the following:

Rule 1: There is no pressure to move the budget into balance from either surplus or deficit. Therefore, on-budget taxes and spending do not adjust in response to changes in the budget balance that arise from Social Security reform.

Rule 2: The political process aims to balance the (cyclically adjusted) unified budget. Therefore, on-budget taxes and spending adjust to achieve unified budget balance.

Rule 3: The political process aims to balance the (cyclically adjusted) on-budget account. Therefore, on-budget taxes and spending adjust to achieve on-budget balance.

Rule 4: The political process aims to balance the unified budget, as in rule 2 , but does so gradually and asymmetrically by eliminating surpluses faster than deficits.

Judging which of these rules might best describe future policymaking is extremely difficult. We include rule 1 solely as a benchmark, because it seems clear that the budget balance does affect tax and spending policy. For example, Auerbach estimates that 30 to 40 percent of the average shock to the unified budget balance during the past fifteen years was reversed through tax or spending changes over the following five years; Henning Bohn finds that the U.S. primary surplus (the surplus excluding interest payments) responds to changes in the debt-GDP ratio. ${ }^{34}$ Yet there 
is little empirical basis for choosing among the other rules. ${ }^{35}$ For the entire period of Auerbach's analysis, the unified budget was in deficit and the onbudget account was in deeper deficit; hence the data exhibit no variation that could allow one to distinguish among rules 2, 3, and 4. As noted earlier, our informal interpretation of the budget process during the past several decades is that 1999 witnessed a striking shift from a traditional focus on unified budget balance to a new focus on on-budget balance. We have little insight into whether that new focus will persist indefinitely (rule 3 ) or revert in the near future (rule 2 or rule 4). Indeed, it is possible to think of other plausible paths: for example, policy might seek to balance the onbudget account until publicly held debt is eliminated, then switch to balancing the unified budget so as to avoid accumulating a national asset. A useful extension to this paper would be an evaluation of the plausibility of these rules in the context of a voting model.

\section{Interaction of Reforms and Political Economy Rules}

Table 3 shows how each of the five canonical elements of Social Security reform would affect national saving under each of the first three political economy rules. We skip the remaining rule as a straightforward variant on the second, and we continue to leave aside any changes in household saving, capital tax revenue, and the return on incremental saving in previous years.

Under rule 1, with no change in other government spending in response to Social Security reform, the change in national saving from Social Security reform equals the change in SST - SSB - WITH. Note that Social Security benefits and withdrawals from individual accounts enter this expression identically: what matters for national saving under this rule is the level of overall retirement benefits, not their source. Cutting Social Security benefits or raising payroll taxes increases saving by Social Security; with no offsetting on-budget response, government saving rises. In contrast, transfers of on-budget revenue to the Social Security

35. Skilling (2000) finds, in a sample of nineteen member countries of the Organization for Economic Cooperation and Development over 1960-99, that fiscal policy is loosened in good economic times but not proportionately tightened in bad economic times (corresponding to our fourth rule). He attributes this result to coordination failure among lossaverse politicians. 
Table 3. Effects of Proposed Social Security Reforms on National Saving under Alternative Political Economy Rules

\begin{tabular}{lccc}
\hline & $\begin{array}{c}\text { Rule 1: } \\
\text { No budget } \\
\text { response }\end{array}$ & $\begin{array}{c}\text { Rule 2: } \\
\text { Balance the } \\
\text { unified } \\
\text { budget }\end{array}$ & $\begin{array}{c}\text { Rule 3: } \\
\text { Balance the } \\
\text { on-budget } \\
\text { account }\end{array}$ \\
\hline $\begin{array}{l}\text { Decrease Social Security } \\
\text { benefits or increase } \\
\text { payroll taxes }\end{array}$ & $\begin{array}{c}\text { Increase saving } \\
\begin{array}{l}\text { Transfer on-budget revenue } \\
\text { to the Social Security } \\
\text { trust fund }\end{array}\end{array}$ & No effect & $\begin{array}{l}\text { Increase saving } \\
\begin{array}{l}\text { Purchase equities for the } \\
\text { Social Security trust fund }\end{array}\end{array}$ \\
$\begin{array}{l}\text { Contribute on-budget } \\
\text { revenue to individual } \\
\text { accounts }\end{array}$ & No effect & No effect ${ }^{\mathrm{a}}$ & Increase saving \\
$\begin{array}{l}\text { Contribute Social Security } \\
\text { revenue to individual } \\
\text { accounts }\end{array}$ & Decrease saving & Noffect & No effect \\
\hline
\end{tabular}

a. Except under a special budget scoring rule whereby transfers of the surplus reduce resources available for other purposes, in which case saving increases.

trust fund raise the Social Security surplus but lower the on-budget surplus by an equal amount, leading to no change in saving. Selling bonds from the trust fund to purchase equities is just a new portfolio choice (or asset swap) and has no effect on saving. (In the next section we discuss the ramifications of equity purchases more fully.) Contributions to individual accounts reduce saving indirectly. The contributions themselves lower government saving but raise saving in individual accounts by an equal amount. However, future withdrawals from the accounts raise consumption, so that national saving declines on balance.

Under rule 2, government saving equals zero, and the change in national saving from Social Security reform equals the saving in individual accounts $(O B C O N+S S C O N-W I T H-C L A W)$. Cutting Social Security benefits or raising payroll taxes increases saving by Social Security, but the incipient unified surplus is entirely dissipated through additional onbudget spending; national saving is unaffected. On-budget transfers to Social Security also have no effect on the unified budget balance, but when the president proposed such transfers in his 1999 State of the Union 
address, his budget reduced the "reported" unified surplus by the amount of the transfers. If this special scoring rule were accepted in the political discourse, other government spending would decline and national saving would increase. Buying equities is, again, simply an asset swap. It does reduce the unified surplus - thereby crowding out other spending - under current budget scoring rules that treat purchases of private securities as outlays. However, our estimates assume that this rule would not persist if the government purchased significant amounts of financial assets. ${ }^{36} \mathrm{In}$ sum, saving in the government sector is impossible under this political economy rule unless the budget process endorses some unnatural scoring convention. Contributions to individual accounts, whether from the onbudget account or from Social Security, engender equal declines in other government spending in order to maintain unified budget balance, and the extra saving associated with account inflows outweighs the reduced saving associated with account withdrawals in all the plans we consider. ${ }^{37}$

Under rule 3, the change in national saving from Social Security reform equals the change in $S S T-S S B-W I T H+T R A N S+O B C O N$. Cutting Social Security benefits or raising payroll taxes increases saving by Social Security; with no opposing on-budget response, government saving rises. On-budget transfers to Social Security increase Social Security saving, and they leave the on-budget surplus unchanged because residual spending declines by the amount of the transfers; again, saving rises. Equity purchases have no effect on saving, as before. Contributions to individual accounts from the on-budget account engender equal declines in on-budget spending, and the saving from these contributions dominates the dissaving from the withdrawals. In contrast, contributions to individual accounts from the Social Security trust fund do not cause any changes in other spending, and so the overall effect is a reduction in saving.

36. How to score the appreciation of stocks held by the trust fund is unclear. We will see later that if the higher return on trust fund assets is allowed to increase the unified budget balance (leading to increases in other spending), investing the trust fund in equities can actually reduce saving. If the Social Security surplus were defined as the change in the trust fund's market value, the unified budget balance would fluctuate with stock prices. If the surplus were defined differently (for example, based on an expected equity return rather than the realized return), the value of trust fund assets could diverge from the cumulative surpluses. Penner (1998) discusses this issue.

37. Contributions to individual accounts could reduce saving if the return earned by the accounts were sufficiently higher than the return earned by other sectors of the economy. 
Table 3 can be summarized as follows. Cutting Social Security benefits or raising payroll taxes boosts national saving unless policymakers aim to balance the unified budget, in which case the freed-up resources are used for other spending or for tax cuts. General revenue transfers to the trust fund raise saving only if policymakers balance the on-budget account or take the transferred amounts off the table in some ad hoc fashion. Equity purchases raise saving only if scoring rules continue to treat these asset swaps as an outlay. Financing individual accounts from the on-budget account raises saving if policymakers balance either the on-budget account or the unified budget; financing individual accounts from the Social Security trust fund increases saving only if policymakers aim to balance the unified budget.

\section{Methodology for Estimating the Impact of Social Security Reform on National Saving}

Our methodology is essentially an accounting exercise, in which we model the inflow, outflow, and accumulation of net assets each year for each sector of the economy. We perform this exercise for alternative Social Security reforms under various assumptions about how the budget policy process, the household sector, and the economy respond to Social Security reform. Our prereform projections of trust fund finances come from the Social Security actuaries, ${ }^{38}$ and our projections of the rest of the budget come from OMB estimates under the president's policy (scaled to the actuaries' projection of GDP).$^{39}$ We also use the actuaries' detailed data to construct a demographic model for tracking individual account balances and withdrawals for each cohort of workers. In this section we describe the remaining aspects of our methodology: our assumptions about capital allocation and rates of return, our treatment of risk, the response of capital taxes to reform, the response of household saving to reform, and the general-equilibrium effects of reform.

38. Board of Trustees of the Federal Old-Age and Survivors and Disability Insurance Trust Funds (2000).

39. OMB (2000a). 


\section{Capital Allocation and Rates of Return}

We assume that incremental national saving is allocated equally to corporate capital, housing capital, and overseas capital. ${ }^{40}$ The empirical evidence on international capital flows suggests that roughly two-thirds of saving in developed countries is retained for domestic investment over long periods, with the remaining third flowing overseas. Martin Feldstein and Charles Horioka found larger values of the saving retention coefficient, but subsequent estimates by Feldstein and Philippe Bacchetta were smaller. ${ }^{41}$ A recent paper by Maurice Obstfeld and Kenneth Rogoff reports that "only" 60 percent of incremental saving by OECD countries remained in the home country between 1990 and $1997 .{ }^{42}$ The increasing integration of global capital markets suggests that domestic retention of saving will drop further over time, and the $\mathrm{CBO}$ has used a 60 percent rate in its modeling. ${ }^{43}$ We are reluctant to put too much weight on the most recent evidence, however, and so we use a value of two-thirds. For domestic capital the Bureau of Economic Analysis calculates that the value of fixed private residential capital at current cost is nearly identical to that of fixed private nonresidential capital. ${ }^{44} \mathrm{We}$ simply assume that incremental domestic investment is divided in the same proportion.

We use the following rates of return. For corporate capital we take James Poterba's estimate of a 7.6 percent real rate of return after paying state and local taxes, which amounts to a nominal rate of return of 11 percent based on the actuaries' projected inflation rate of 3.2 percent. ${ }^{45}$ For government bonds issued to the trust fund, we adopt the actuaries' projected nominal rate of return of 6.3 percent (following a brief transition). We assume that the rate of return on government bonds sold to the public is 20 basis points lower than that, because public debt has shorter average

40. We ignore noncorporate, nonhousing capital for simplicity. This omission distorts our results only to the extent that the return and the tax rate on that asset differ from the average return and tax rate on the assets we include.

41. Feldstein and Horioka (1980); Feldstein and Bacchetta (1991).

42. Obstfeld and Rogoff (2000).

43. CBO (1997b).

44. Bureau of Economic Analysis (1997).

45. Poterba (1998). Specifically, $1.076 \times 1.032=1.11$. In using the return after state and local taxes, we are assuming that those governments spend rather than save any additional revenue they receive. 
maturity; that the rate of return on corporate debt is 50 basis points higher, because of its greater risk (this is the value used by the actuaries); that the return on equity is 390 basis points higher, producing a 7 percent real rate of return (this is the value assumed by the 1994-1996 Advisory Council and used in the actuaries' scoring of reform proposals); and that the rate of return on housing and overseas capital (which we generally combine for simplicity) is 260 basis points higher. We calculate the last value by assuming that after-tax returns to housing, overseas, and corporate capital all equilibrate (assuming implicitly that the assets are equally risky); we describe the tax rates below. We assume that corporate capital is financed with debt and equity in a 1:3 ratio, a choice that compromises between the estimates of Auerbach and Poterba. ${ }^{46}$ The returns on equity and debt are consistent with the underlying return to corporate capital after corporate income tax (based on the tax rate shown below). Moreover, the returns on corporate and housing capital are consistent with Elmendorf and Gregory Mankiw's estimate of the overall rate of return to capital. ${ }^{47}$

\section{Treatment of Risk}

Like much analysis of Social Security reform, as well as official Social Security and budget projections, our methodology is based on the expected values of future variables. Yet the uncertainty surrounding those expectations is very large: we have already discussed the uncertainty of budget forecasts and noted Lee and Tuljapurkar's estimate that a 95 percent confidence interval for Social Security benefits in 2070 ranges from 16 percent of payroll to twice that share. Moreover, political risk regarding future benefit and tax rules may be quite important.

Some of our estimates are invariant to certain kinds of risk: under the three political economy rules that treat surpluses and deficits symmetrically, changes in the baseline budget balance do not change the estimated effect of reform on national saving. And a few of our estimates explore sensitivity to risk: for the asymmetric rule, we report saving effects under both the official baseline and a more pessimistic one. In general, however, we leave risk aside as an issue beyond the scope of this paper. 
One area in which risk cannot be wholly ignored, however, is the return to different assets. When the Social Security actuaries analyze reform proposals, they assume that equities will earn a substantially higher return than bonds; as a result, increasing the equity share of the trust fund or of individual accounts allows for longer solvency or higher benefits without raising taxes or contributions. The apparent implication of an arbitrage opportunity in portfolio choice has raised strong concerns, ${ }^{48}$ and a growing literature considers the appropriate accounting for equity risk in evaluating reform proposals and the appropriate allocation of equity risk in a reformed system. ${ }^{49}$

The key point for our purpose is that swapping assets between sectors has no effect on national saving..$^{50}$ Our methodology captures this principle naturally: we track the holdings of each asset by each sector, so that trust fund equity purchases (and corresponding bond sales) reduce the return on household wealth by exactly the amount that they raise the return on the trust fund. The crucial uncertainty we cannot avoid involves the marginal product of capital. If capital earns a lower or higher return in the future, near-term saving will have a smaller or a larger effect, respectively, on the ultimate capital stock. Our estimates that incorporate the general-equilibrium effects of reform provide some sensitivity analysis on this issue, because those estimates involve varying returns to capital.

48. For example, see 1999 Technical Panel on Assumptions and Methods (1999).

49. For example, see Smetters $(1998,1999)$ and Feldstein, Ranguelova, and Samwick (1999). Some of the popular appeal of equity investments may stem from a more basic confusion. The return on Social Security taxes is now well below average returns on private retirement accounts, and part of this difference arises because private accounts tend to hold riskier assets than the government bonds held by the trust fund. Yet most of the difference is unrelated to investment strategy and is due to the implicit debt that arises in pay-asyou-go systems from paying benefits to initial generations in excess of their contributions. Geanakoplos, Mitchell, and Zeldes (1998) explain the differences between privatization, prefunding, and diversification.

50. There are some circumstances under which equity investments by Social Security may be more than just an asset swap. Abel (2000) and Diamond and Geanakoplos (1999) explore the general-equilibrium effects of reform in the case of market imperfections that discourage some households from owning equities. However, these effects are likely to be much smaller than the effects studied in this paper. Abel (2000) finds that accounting for these effects would reduce the aggregate capital stock by only $\$ 138$ million (50 cents per capita). 


\section{The Response of Capital Taxes to Social Security Reform}

If Social Security reform affects national saving or redirects existing saving to untaxed individual accounts, it will also affect government revenue from capital taxes. Indeed, some reform proposals treat such incremental revenue as an important source of funding. ${ }^{51}$

Our calculations of incremental capital tax revenue are based on Auerbach's estimates of effective tax rates. ${ }^{52}$ For corporate capital we combine his estimates of the shares of debt and equity held by households, taxexempt institutions, and insurance companies with his estimates of real tax rates on interest, dividends, and capital gains for each of these asset holders to construct real tax rates on returns to bonds and equities. Given these rates and Auerbach's estimate of the total tax burden on corporate capital, we derive the real tax rate at the corporate level. This rate is well below the tax rate on corporate profits, because part of the total capital return is distributed through interest payments that are not taxed at the corporate level. ${ }^{53}$ These estimates of real tax rates are quite consistent with Poterba's calculations for the 1990-96 period. ${ }^{54}$ Finally, we convert these real tax rates to nominal rates in order to link up with the actuaries' projections of Social Security's nominal flows. ${ }^{55}$ For housing capital we use Auerbach's estimate of the individual tax rate converted to nominal terms. For overseas capital we assume an effective tax rate at the corporate level of zero and an effective rate at the individual level that is the same as that for domestic corporate capital. ${ }^{56}$

51. Feldstein and Samwick $(1998,2000)$.

52. Auerbach (1996).

53. Auerbach reports a "corporate tax rate" that is effectively the rate on corporate equity capital, and he combines the deductibility of payments on corporate debt capital with the individual tax on equity and interest income. That grouping is misleading for our purpose, which is to determine the tax revenue from assets that are held in untaxed individual accounts.

54. Poterba (1998).

55. Specifically, we calculate the nominal tax rate that produces the same after-tax real return. With corporate capital, for example, a real tax rate of 21.7 percent corresponds to a nominal tax rate of 15.4 percent when inflation is 3.2 percent and the real before-tax return is 7.6 percent: $1+0.076 \times(1-0.217)=\{1+[(1+0.076) \times(1+0.032)-1] \times(1-$ $0.154)\} /(1+0.032)$. Our calculated nominal tax rates at the individual level are 6.6 percent for equities, 9.9 percent for bonds, 3.2 percent for housing, and 7.8 percent on foreign capital.

56. These assumptions are not precisely correct. Because credits for taxes paid overseas cannot exceed domestic tax liability (but can fall short of it), corporate tax revenue from 
To illustrate our tax calculations, consider the effect of contributing $\$ 100$ from the Social Security trust fund to individual accounts (a "carveout") in a political regime that balances the unified budget. Government saving is unchanged, and saving in individual accounts rises by $\$ 105$ : the $\$ 100$ transfer plus a within-year return of about $\$ 5$. The incremental $\$ 105$ in national saving produces $\$ 35$ each of additional corporate, housing, and overseas capital; the stock of government bonds is unchanged. The change in tax revenue can be decomposed into the effect of adding $\$ 105$ to household wealth and the effect of shifting \$105 into individual accounts that are untaxed at the personal level. For the first effect, the extra revenue from corporate capital is $\$ 0.85$ ( $\$ 35$ times the 11 percent rate of return times the 22 percent combined corporate and individual tax rate), and the extra revenue from housing and overseas capital is $\$ 0.35$ ( $\$ 70$ times the 9.1 percent rate of return times the 5.5 percent individual tax rate). For the second effect, we assume that individual account balances are 60 percent equities and 40 percent government bonds, so the weighted-average return after corporate tax is 8.7 percent, and the individual tax rate if the assets were held directly by households would be 7.5 percent. Thus the loss in revenue from the shift to individual accounts is $\$ 0.69$ ( $\$ 105$ times 8.7 percent times 7.5 percent), and the net revenue gain is $\$ 0.51$, or roughly 0.5 percent of the $\$ 100$ contribution.

Moreover, this example ignores any reduction in household saving spurred by the funding of individual accounts. As we explain shortly, some of our calculations assume that a $\$ 100$ contribution to individual accounts would reduce household saving by $\$ 40$. In this scenario the change in tax revenue can be decomposed into the effects of adding $\$ 65$ to household wealth and shifting $\$ 105$ into untaxed accounts-with a net increase in revenue of only $\$ 0.03$.

Even our larger estimate is only one-quarter of the 2.0 percent effective tax rate used by Feldstein and Andrew Samwick. ${ }^{57}$ The difference stems from two factors. First, we assume that two-thirds of the additional capital goes overseas or into housing, where it is taxed at a lower rate

direct overseas investments is small but nonzero. Also, Hines (1996) shows that firms pay more dividends out of their foreign earnings, so the effective personal tax rate is somewhat higher on foreign capital.

57. Feldstein and Samwick (2000). 
than in the corporate sector. If we followed Feldstein and Samwick in assuming that only one-fifth of incremental capital went outside the corporate sector and that the effective tax rate on that capital was zero, incremental taxes would rise to $\$ 1.34$. Second, we use a lower corporate tax rate, which accounts for the remaining difference.

\section{The Response of Household Saving to Social Security Reform}

We determine household saving using simple rules of thumb rather than a formal optimizing model. We assume that households save all of their incremental after-tax capital income and respond to three aspects of Social Security reform, described below. Although the magnitude of these responses is very uncertain, the impact of household behavior on our estimates of national saving under alternative reforms is too important to be omitted..$^{58}$

We assume that households increase their saving by 25 percent of any increase in the unified budget deficit, so that a $\$ 1$ rise in the deficit would lower national saving by only 75 cents. Part of the change in household saving can be attributed to forward-looking consumers who realize that additional government debt will force higher future taxes; another part may be a reaction to higher interest rates as additional debt crowds out private capital. Large literatures on these topics have not reached a consensus on the size of these effects, ${ }^{59}$ but we choose a response somewhat smaller than the 40 percent offset used by the CBO (1999).

We also assume that households increase their saving by 25 percent of any reduction in future Social Security benefits. ${ }^{60}$ This value is the midpoint in the CBO's assessment of research on this issue: "Each dollar of Social Security wealth reduces other assets by between zero and 50 cents," although "those estimates are uncertain, and higher or lower estimates cannot be ruled out." ${ }^{61}$

58. Engen and Gale (1997) offer a detailed discussion of this topic.

59. Elmendorf and Mankiw (1999); Elmendorf (1996).

60. We do not model a household response to improvements in the trust fund's financial position. Although such improvements increase the likelihood of people receiving currentlaw benefits, all of the plans we consider achieve seventy-five-year solvency for Social Security, and therefore greater confidence about benefits should not have a differential effect across plans.

61. CBO (1998), p. 3. 
Lastly, we assume that households decrease their saving by 40 percent of future withdrawals from individual accounts that will be available for consumption (rather than be clawed back or taxed). We choose an offset larger than for Social Security benefits because the tangibility of the accounts may be a stronger deterrent to saving. (On the other hand, individual accounts could actually increase other saving by sensitizing people to the importance of retirement planning.) The extensive empirical evidence on the saving impact of individual retirement accounts (IRAs) and $401(\mathrm{k}) \mathrm{s}$ cannot be applied directly here because the policy experiments are different. ${ }^{62}$ It seems clear that the net impact on saving is more likely to be positive if individual accounts are funded in a redistributive manner that provides larger contributions relative to earnings for lowearning individuals. The reason is that low-income households have fewer assets to draw down and are less likely to have employer-provided pensions that could be trimmed. On balance, however, we believe that individual accounts are likely to crowd out some other household saving. ${ }^{63}$

\section{General-Equilibrium Effects of Social Security Reform}

If Social Security reform affects national saving and the domestic capital stock, it will also affect the returns on capital and labor. These generalequilibrium effects change the rate at which incremental saving in each year cumulates over time, as well as alter the Social Security tax base and, eventually, Social Security benefit levels.

We estimate the effect of additional capital accumulation on the returns to capital and labor by parameterizing a Cobb-Douglas production function. We assume a capital share of 0.31 and an initial capital-output ratio of 3.2 (both taken from average levels in the United States between 1960 and 1997). ${ }^{64}$ Then we calculate the changes in the marginal products of capital and labor as additional saving occurs. We assume that all asset returns decline in the same proportion as does the marginal product of capital (this best captures the combination of two factors: that the various

62. For examples of studies on the impact on saving of these existing types of accounts, see Poterba, Venti, and Wise (1996) and Engen, Gale, and Scholz (1996).

63. Samwick (2000) presents evidence consistent with a crowding out of saving and concludes that there is "little evidence that countries that implement defined-contribution reforms have higher trends in saving rates after the reform."

64. These calculations update similar calculations in Elmendorf and Mankiw (1999). 
real returns decline by the same absolute amount but that the inflation rate and the tax rate do not change). This effect is nontrivial: an increase in the capital stock equal to 100 percent of prereform GDP reduces the marginal product of capital by roughly $13 / 4$ percentage points. Additional saving also increases the marginal product of labor, which we incorporate into our calculations of payroll tax receipts and Social Security benefit levels. ${ }^{65}$ However, we ignore any induced change in labor supply and assume that changes in the return to inframarginal capital and labor are offsetting for the on-budget account and for household saving.

\section{Results}

This section presents our basic results regarding the effect of Social Security reform on national saving; the following section gives results for a number of interesting extensions.

\section{Reform Proposals}

Table 4 summarizes seven hypothetical Social Security reforms that represent the range of reform proposals introduced in Congress or discussed during the past several years.

TRANSFERRING THE ON-BUDGET SURPLUS TO THE TRUST FUND. This approach was proposed by President Clinton in his 1999 State of the Union address, and in a modified form in his mid-session review of the budget later that year. In contrast to most other reform proposals, these proposals do not achieve seventy-five-year solvency for the trust fund; they are explicitly incomplete, and the president called for a bipartisan process to determine further steps. For comparability with the other reform approaches, we analyze not the administration's proposal but a hypothetical plan that makes sufficient transfers from the on-budget account to achieve seventy-five-year solvency with no other changes. The OMB projects that on-budget surpluses (incorporating the administration's tax and spending policies) will last until about 2060 and total about $\$ 3.4$ trillion

65. Bosworth and Burtless (2000) analyze the general-equilibrium effects of Social Security reform on workers with different earnings profiles. 
Table 4. Proposals to Reform Social Security

\begin{tabular}{ll}
\hline Reform proposal & \multicolumn{1}{c}{ Description } \\
\hline Transfer surplus to trust fund & $\begin{array}{l}\text { Use on-budget surpluses to purchase Treasury bonds } \\
\text { for the Social Security trust fund. These transfers } \\
\text { total } \$ 3.4 \text { trillion in present value and extend Social } \\
\text { Security's solvency to } 2075 .\end{array}$
\end{tabular}

Invest half the trust fund in equities Invest 50 percent of Social Security trust fund assets in equities over ten years. An 11 percent benefit cut is phased in linearly over thirty years. The ratio of trust fund assets to benefit payments is stable in 2075 .

Add-on individual accounts

Contribute on-budget revenue equal to 2 percent of payroll to individual accounts. Withdrawals are taxed like Social Security benefits. A 32 percent cut in traditional benefits is phased in as account withdrawals increase (11 percent of the cut after twenty years, 58 percent after forty years, 87 percent after fifty years). Social Security is in pay-as-you-go balance in 2075 .

Clawback

Contribute on-budget revenue equal to 2 percent of payroll to individual accounts. Seventy-five percent of redemptions are clawed back to the trust fund. Remaining withdrawals are taxed like Social Security benefits. A 6 percent cut in traditional benefits is phased in as account withdrawals increase. The ratio of trust fund assets to benefit payments is stable in 2075.

Carve-out

Contribute 2 percent of payroll from the trust fund to individual accounts. Withdrawals are taxed like Social Security benefits. A 37 percent cut in traditional benefits is phased in linearly over thirty years (faster than the buildup of the accounts). The ratio of trust fund assets to benefit payments is stable in 2075 .

Carve-out with transfers

Contribute 2 percent of payroll from the trust fund to individual accounts. Withdrawals are taxed like Social Security benefits. Transfer general revenue equal to 2 percent of individual account assets to the trust fund. A 33 percent cut in traditional benefits is phased in as account withdrawals increase. The trust fund balance is negative between about 2030 and 2070 but positive and rising in 2075.

Payroll tax increase Raise the payroll tax, beginning in 2015, to maintain annual pay-as-you-go balance in Social Security. 
in present value; ${ }^{66}$ our hypothetical plan transfers those surpluses to the trust fund.

INVESTING HALF THE TRUST FUND IN EQUITIES. Some authors propose investing part of the trust fund in equities, and this change was included in President Clinton's proposals ${ }^{67}$ We examine a plan in which 50 percent of trust fund assets are invested in equities (phased in over ten years), a much larger share than the 15 percent in the president's plan but comparable to other proposals. To achieve a stable ratio of trust fund assets to benefit payments in 2075, we include an 11 percent benefit cut phased in linearly over thirty years. This cut approximates the financial impact of reforms that are often part of this type of plan, such as raising the retirement age and including more state and local government workers in Social Security.

ESTABLISHING ADD-ON INDIVIDUAL ACCOUNTS. Our model plan contributes on-budget revenue equal to 2 percent of payroll to individual accounts; these accounts are invested 60 percent in corporate equities and 40 percent in government bonds, with annual administrative costs equal to 40 basis points. Withdrawals from the accounts are taxed like Social Security benefits. To achieve pay-as-you-go balance in Social Security in 2075, we include a 32 percent benefit cut phased in roughly at the rate that account withdrawals increase. (A 29 percent benefit cut would be sufficient to meet the weaker standard of a stable trust fund ratio in 2075.) This phase-in is fairly slow: even after forty years, significant numbers of retirees will have contributed to individual accounts for only a portion of their careers, so that only 58 percent of the ultimate Social Security benefit cut is imposed by that point. ${ }^{68}$

CLAWING BACK A PORTION OF WITHDRAWALS. Feldstein and Samwick as well as Representatives William Archer (R-TX) and Clay Shaw (R-FL) have proposed an alternative way to use budget surpluses to prefund future retirement benefits. ${ }^{69}$ Their plans would establish individual accounts comparable to the add-on accounts just discussed, but withdrawals from the accounts would effectively be taxed at a very high rate and the proceeds

66. OMB (2000a).

67. Ball and others (1997); Ball (1998); Aaron and Reischauer (1998).

68. Feldstein and Liebman (2000) analyze the intracohort distributional impact of a fully phased-in plan of this type.

69. Feldstein and Samwick (1998); Archer and Shaw (1999). 
used to finance traditional benefits. Individuals would control the investments in these accounts, but the trust fund would be the ultimate claimant on most of their value; thus this approach is sometimes viewed as a way to keep investment decisions in private hands while allowing Social Security to realize the higher expected return on equities. However, the viability of a 75 percent or higher tax rate is unclear. ${ }^{70}$ We analyze a plan in which 75 percent of the withdrawals from individual accounts (funded by 2 percent of payroll from on-budget revenue as in the previous plan) are clawed back. We include a 6 percent benefit cut phased in with the buildup of individual accounts to achieve a stable trust fund ratio in 2075.

CREATING A CARVE-OUT. The Personal Savings Accounts proposal of the 1994-1996 Advisory Council would have diverted 5 percentage points of the existing 12.4 percent Social Security payroll tax to individual accounts. The remainder of the tax would have paid for current-law disability and survivor benefits and for much smaller Social Security retirement benefits. ${ }^{71}$ We analyze a smaller carve-out of 2 percentage points of the payroll tax, similar to that proposed by Senators John Breaux (D-LA) and Judd Gregg (R-NH) and Representatives Jim Kolbe (R-AZ) and Charles Stenholm (D-TX). To achieve a stable trust fund ratio in 2075 , we include a 37 percent cut in traditional Social Security benefits phased in linearly over thirty years (substantially faster than the buildup of the individual accounts).

COMBINING A CARVE-OUT WITH TRANSFERS. Various hybrid reform proposals combine features of the first five plans. For example, some proposals would transfer on-budget revenue to both the trust fund and individual accounts. In this case the trust fund investments could mirror individuals' investment decisions for their accounts, thus addressing some of the corporate governance concerns related to collective investing in a somewhat different fashion than in the clawback plans. To illustrate the ways in which plans can be combined, we study a different hybrid plan modeled after Feldstein and Samwick, ${ }^{72}$ which combines a carve-out individual

70. The clawback can also be specified as a reduction in Social Security benefits equal to some fraction of the account withdrawals. For example, a worker might lose 75 cents of Social Security benefits for each dollar of retirement income from an individual account.

71. This carve-out proposal would have replaced part of the progressive Social Security benefit with an individual account that was funded with contributions proportional to a worker's earnings. To maintain redistribution from high earners to low earners, this proposal would have converted the remaining benefit to a benefit that was equal for all retirees.

72. Feldstein and Samwick (2000). 
account with transfers from general revenue to the trust fund. We analyze a version of their plan that includes a carve-out of 2 percent of payroll, a 33 percent Social Security benefit cut phased in at the same rate that account withdrawals increase, and annual general revenue transfers equal to 2 percent of the value of total assets in individual accounts in that year. These parameters produce a negative trust fund balance between about 2030 and 2070, but the trust fund balance is positive and rising by $2075 .{ }^{73}$

INCREASING THE PAYROLL TAX. We analyze the effect of raising the payroll tax, beginning in 2015, to maintain annual pay-as-you-go balance in Social Security. This approach has not been part of the recent political debate, but it provides a useful counterpoint to plans that emphasize prefunding and equity returns.

\section{Capital Accumulation under Different Political Economy Rules}

Table 5 shows the effect of each of these reform plans on capital accumulation in 2070, expressed as percentages of GDP under the prereform baseline. To focus for now on the political response to reform, these estimates ignore changes in capital tax revenue, household saving, and changes in the returns to capital and labor. We follow equation (2) in decomposing the change in capital accumulation (the last column) into the effect of cuts in Social Security benefits and increases in payroll taxes (the first column), increases in consumption through individual accounts (the second column), and declines in spending or increases in taxes in the non-Social Security part of the budget (the third column).

The first panel displays results for political economy rule 1 . Because under this rule the non-Social Security budget does not respond to Social Security reform, the third effect is zero for all plans. Transferring onbudget resources to the trust fund has no effect on capital accumulation

73. Feldstein and Samwick describe their transfers (which in our estimates total $\$ 3.1$ trillion in present value over the next seventy-five years) as the extra tax revenue from incremental capital accumulation, assuming that each dollar of assets held by individual accounts generates 2 cents of tax revenue. Although our implementation of their plan makes the transfers that they specify, our analysis, described above, suggests that the extra tax revenue from incremental capital will be much smaller: only 0.5 cent on the dollar. In their analysis, Feldstein and Samwick estimate that the trust fund balance becomes positive at an earlier date than we do. This difference appears to arise from their assumption that individual accounts are invested in a 60-40 stock-bond portfolio even after retirement, whereas we assume that retirees shift to an all-bond portfolio. 
Table 5. Effects of Proposed Social Security Reforms on Capital Accumulation in 2070 under Alternative Political Economy Rules ${ }^{\text {a }}$

Percent of 2070 baseline GDP

\begin{tabular}{|c|c|c|c|c|}
\hline \multirow[b]{2}{*}{ Reform proposal } & \multicolumn{3}{|c|}{ Capital accumulation from } & \multirow[b]{2}{*}{$\begin{array}{c}\text { Total } \\
\text { capital } \\
\text { accumulation }\end{array}$} \\
\hline & $\begin{array}{c}\text { Social Security } \\
\text { benefit cut or } \\
\text { payroll tax } \\
\text { increase }\end{array}$ & $\begin{array}{c}\text { Consumption } \\
\text { from } \\
\text { individual } \\
\text { accounts }\end{array}$ & $\begin{array}{c}\text { Decrease in } \\
\text { on-budget } \\
\text { spending }\end{array}$ & \\
\hline \multicolumn{5}{|l|}{ Rule 1: No budget response } \\
\hline Transfer surplus to trust fund & 0 & 0 & 0 & 0 \\
\hline \multicolumn{5}{|l|}{ Invest half the trust fund } \\
\hline Add-on individual accounts & 180 & -209 & 0 & -28 \\
\hline Clawback & 36 & -78 & 0 & -41 \\
\hline Carve-out & 505 & -209 & 0 & 296 \\
\hline Carve-out with transfers & 186 & -209 & 0 & -22 \\
\hline Payroll tax increase & 295 & 0 & 0 & 295 \\
\hline \multicolumn{5}{|c|}{ Rule 2: Balance the unified budget } \\
\hline Transfer surplus to trust fund & 0 & 0 & $0(110)^{b}$ & $0(110)$ \\
\hline \multicolumn{5}{|l|}{ Invest half the trust fund } \\
\hline in equities & 144 & 0 & -351 & -207 \\
\hline Add-on individual accounts & 180 & -209 & 140 & 111 \\
\hline Clawback & 36 & -78 & 153 & 111 \\
\hline Carve-out & 505 & -209 & -185 & 111 \\
\hline Carve-out with transfers & 186 & -209 & $134(211)$ & $111(188)$ \\
\hline Payroll tax increase & 295 & 0 & -295 & 0 \\
\hline \multicolumn{5}{|c|}{ Rule 3: Balance the on-budget account } \\
\hline Transfer surplus to trust fund & 0 & 0 & 331 & 331 \\
\hline $\begin{array}{l}\text { Invest half the trust fund } \\
\text { in equities }\end{array}$ & 144 & 0 & 6 & 150 \\
\hline Add-on individual accounts & 180 & -209 & 336 & 307 \\
\hline Clawback & 36 & -78 & 336 & 294 \\
\hline Carve-out & 505 & -209 & 6 & 302 \\
\hline Carve-out with transfers & 186 & -209 & 184 & 161 \\
\hline Payroll tax increase & 295 & 0 & 13 & 308 \\
\hline
\end{tabular}

Source: Authors' calculations.

a. Excludes capital taxation, household saving, and general-equilibrium effects.

b. Numbers in parentheses are calculated using a special budget scoring rule whereby transfers of the surplus reduce resources available for other purposes.

because it does not change Social Security benefits or taxes and does not establish individual accounts. The plan that invests half of the trust fund in equities boosts the capital stock not because of the investment switch but because of the benefit cuts that are a part of this plan. The plan with add-on individual accounts reduces capital accumulation relative to the 
baseline because additional consumption from account withdrawals slightly exceeds the reduced consumption from Social Security benefit cuts. In other words, total retirement benefits are slightly higher in this plan than under current law, and this crowds out a small amount of capital. The clawback plan also reduces the capital stock a bit, with a smaller cut in traditional benefits creating less new saving, but with the individual accounts generating less dissaving because people keep only a portion of their withdrawals. ${ }^{74}$

The carve-out plan increases the capital stock substantially, as the rapid benefit cut more than compensates for the additional consumption from individual accounts. In contrast, the carve-out with transfers reduces the capital stock a little because the benefit cuts are smaller and phased in more slowly. This plan and the add-on individual accounts plan have nearly identical effects on capital accumulation, because each combines accounts funded by 2 percent of payroll with cuts of roughly 30 percent in traditional benefits. More fundamentally, the plans add about the same amount of extra resources to each part of the retirement system but package it differently. The add-on plan contributes on-budget revenue equal to 2 percent of payroll to individual accounts, whereas the carve-out with transfers directs roughly the same amount to the trust fund while simultaneously redirecting that amount from the trust fund to individual accounts. Indeed, the clawback plan also injects 2 percent of payroll into the retirement system (with yet a different packaging) and has nearly the same effect on saving. Finally, a pay-as-you-go increase in the payroll tax leads to a substantial amount of new capital because of the increase in government saving.

The second panel of table 5 shows the effect of the same plans under political economy rule 2 , in which on-budget spending or taxes adjust to balance the unified budget. The first two columns are identical to the corresponding columns in the first panel, because the Social Security reform plans specify benefit cuts, payroll tax increases, and individual account withdrawals. The novelty in this panel is the numbers in the third column, which are the effects of changes in on-budget spending. Transferring onbudget revenue to the trust fund still has no effect on saving unless the polit-

74. Because the clawback rate is 75 percent, one might wonder why the reduced capital accumulation due to consumption from individual accounts in the clawback plan is not one-fourth of the reduction under the add-on plan. The explanation is that this column includes the resources devoted to administrative costs, which do not depend on the existence or size of a clawback. 
ical process adopts the special scoring rule initially proposed by the Clinton administration, in which the reported surplus (and thereby the funds available for other purposes) is reduced by the amount of the transfers. A key feature of this political economy rule, which balances the unified budget, is that benefit cuts and payroll tax increases are exactly offset by increases in on-budget spending. Thus the plan that invests half of the trust fund in equities reduces capital accumulation, because the benefit cuts are offset by extra non-Social Security spending, and the higher return to the trust fund increases the unified budget surplus and allows yet more spending.

The three plans that establish individual accounts without transfers to the trust fund all boost capital accumulation by the same amount under rule 2. This result arises because the different levels of benefit cuts in these plans are of no consequence in a unified budget world, and all three plans fund individual accounts using 2 percent of payroll. The add-on plan reduces capital accumulation by 28 percent of GDP (as shown in the first panel of table 5) through the net effect of lower Social Security benefits (180 percent of GDP) and consumption from individual accounts (209 percent of GDP). On the other hand, under rule 2, the plan generates additional capital equal to 140 percent of GDP through cuts in on-budget spending. This last figure can be broken down into an increase of 320 percent of GDP due to spending crowded out by contributions to the accounts, and a decrease of 180 percent of GDP due to spending crowded in by the benefit cut. In other words, the traditional benefit cut has no net impact on national saving under this political economy rule, whereas the saving in the individual accounts (contributions less withdrawals) passes through to national saving. The clawback plan makes the same account contributions and the same withdrawals, and so it has the same effect on saving. The carve-out plan has the same effect as well, because the larger benefit cut that boosted its saving impact in the first panel is now offset by higher on-budget spending. ${ }^{75}$

The carve-out with transfers has the same effect on saving as the other individual account plans under conventional scoring rules, but a larger effect under the special scoring rule because the transfers crowd out addi-

75. In the clawback plan, the incremental capital from lower on-budget spending153 percent of GDP-equals an increase of 320 percent due to account contributions plus decreases of 36 percent and 131 percent due to offsets of the traditional benefit cut and clawback revenue. In the carve-out plan, reduced capital from higher on-budget spending-185 percent of GDP-equals the same 320 percent less 505 percent from the extra spending allowed by the larger benefit cut. 
tional on-budget spending. Pay-as-you-go tax increases have no effect on saving under this budget rule, because the incipient increase in the unified budget balance is dissipated in the on-budget account.

The third panel of table 5 shows the effect of the plans under political economy rule 3 , in which taxes and spending adjust to balance the non-Social Security part of the budget. Transfers of on-budget revenue to the trust fund now crowd out other spending and increase saving. Indeed, such transfers boost saving much more than under the special scoring rule in the previous panel, because the on-budget balance is reduced by interest on previous transfers, a feature that was not part of the special scoring rule. The plan that invests half of the trust fund in equities has essentially the same effect as in the first panel, with the extra capital generated primarily by the traditional benefit cut. ${ }^{76}$

The add-on, clawback, and carve-out plans increase saving by nearly equal amounts under this rule. The first two plans-as well as the onbudget transfers to the trust fund-take 2 percent of payroll out of the on-budget account; the carve-out plan saves no on-budget resources, but it reduces traditional Social Security benefits by an equivalent additional amount in order to maintain solvency in the trust fund. Saving under all three plans is much higher than in the middle panel, primarily because cuts in traditional benefits are not offset by higher on-budget spending. The carve-out with transfers raises saving by less than the preceding plans, because its transfers (and the resulting crowding out of on-budget spending) occur later. ${ }^{77}$ Lastly, the pay-as-you-go tax increase raises saving in Social Security, and unlike in the second panel there is no offsetting increase in other spending. ${ }^{78}$

In summary, table 5 reveals four principles about the effect of Social Security reform on capital accumulation. First, a given reform plan can

76. The small difference relative to the first panel is due to a small decline in on-budget spending, which results from different rates of return on trust fund debt and publicly held debt.

77. We stated earlier that transfers in this plan are roughly equal to the use of on-budget resources by the add-on and clawback plans. That statement referred to present values discounted by the return on the government bonds held by the trust fund. In the present context, the relevant discount rate is the marginal product of capital, so these back-loaded transfers become relatively less valuable.

78. The small difference relative to the first panel is due to a small decline in on-budget spending, which results from different rates of return on trust fund debt and publicly held debt. 
have very different effects on saving depending on the response of non-Social Security taxes and spending. Only three of the seven plans increase saving if there is no change in other taxes and spending, but all seven plans raise saving under one or both of the other political economy rules. Second, reform plans that seem very different can have nearly identical effects on saving. This occurs both because many plans have similar total retirement benefits (based on similar amounts of new funding, packaged in different ways) and because budget responses offset some differences among plans. Third, programmatic prefunding ensures economic prefunding (that is, increased national saving) only if the political process balances the budget excluding Social Security. Thus only in the bottom panel of the table do tax increases, benefit cuts, general-revenue contributions to individual accounts, and general-revenue transfers to the trust fund all raise saving. Fourth, if policymakers balance the unified budget (leaving aside the possibility of special scoring rules), reform plans can boost saving only by moving money out of the government to individual accounts. Indeed, much of the favorable saving effect of the individual account plans comes from taking money off the table for other spending or tax cuts, and that is why the saving impacts mostly increase as one moves from the first panel to the other two panels.

\section{Extensions}

We now explore our basic results more thoroughly and extend them in several ways.

\section{Benefit Levels and Equity Investment}

Tables 6 and 7 provide additional insight into the estimates in table 5 by highlighting the benefit levels and role of equity investments, respectively, for each reform proposal. Table 6 shows traditional Social Security benefits, withdrawals from individual accounts, and total retirement benefits (the sum of the first two columns) in 2070, all as percentages of baseline GDP. The level of total retirement benefits is strikingly similar among five of the seven proposals. Except for the plan that invests half the trust fund in equities and the carve-out plan, all of the plans we examine keep retirement benefits in 2070 within 2 percent of the current-law level. Under 
Table 6. Retirement Benefits in 2070 under Proposed Social Security Reforms ${ }^{\mathrm{a}}$

Percent of 2070 baseline GDP

\begin{tabular}{lccc}
\hline Reform proposal & $\begin{array}{c}\text { Social } \\
\text { Security }\end{array}$ & $\begin{array}{c}\text { Individual } \\
\text { accounts }\end{array}$ & Total \\
\hline No reform & 6.8 & 0.0 & 6.8 \\
Transfer surplus to trust fund & 6.8 & 0.0 & 6.8 \\
Invest half the trust fund in equities & 6.1 & 0.0 & 6.1 \\
Add-on individual accounts & 4.7 & 2.1 & 6.8 \\
Clawback & 6.4 & 0.5 & 6.9 \\
Carve-out & 4.4 & 2.1 & 6.5 \\
Carve-out with transfers & 4.7 & 2.1 & 6.8 \\
Payroll tax increase & 6.8 & 0.0 & 6.8 \\
\hline
\end{tabular}

Source: Authors' calculations.

a. Excludes capital taxation, household saving, and general-equilibrium effects.

the first political economy rule (no budget response), the level of total benefits is generally a good predictor of the saving effect of reform. Thus, in the top panel of table 5, four of the five plans with similar benefit levels also have similar effects on capital accumulation; the exception is the pay-as-you-go tax increase, which boosts saving through high taxes. ${ }^{79}$

The composition of total benefits is quite different among the five plans with similar total benefits: some plans stay entirely with traditional benefits, whereas others replace those benefits to a greater or lesser degree with individual accounts. Benefit composition is very important for the economic and political risk faced by beneficiaries, the level of administrative costs, and the political durability of the plans; it is also important for the saving effect of reform if the political process balances the unified budget. Comparing table 6 with the middle panel of table 5 shows that plans with higher individual account benefits tend to increase capital accumulation more than do other plans.

Table 7 examines the role of equity investments in the reform plans. As explained earlier, our methodology tracks asset swaps among sectors, and therefore shifts of Social Security or individual account balances into equities have no direct effects on national saving. However, such investments do allow the public retirement system - the trust fund and individ-

79. The effects on capital accumulation are not necessarily identical for plans with identical total benefits in 2070 because the plans may have different benefit paths during the intervening years. Similarly, the carve-out plan accomplishes more saving than the plan that invests half of the trust fund in equities, even though it has higher benefit levels in 2070, because its benefit cuts occur earlier. 


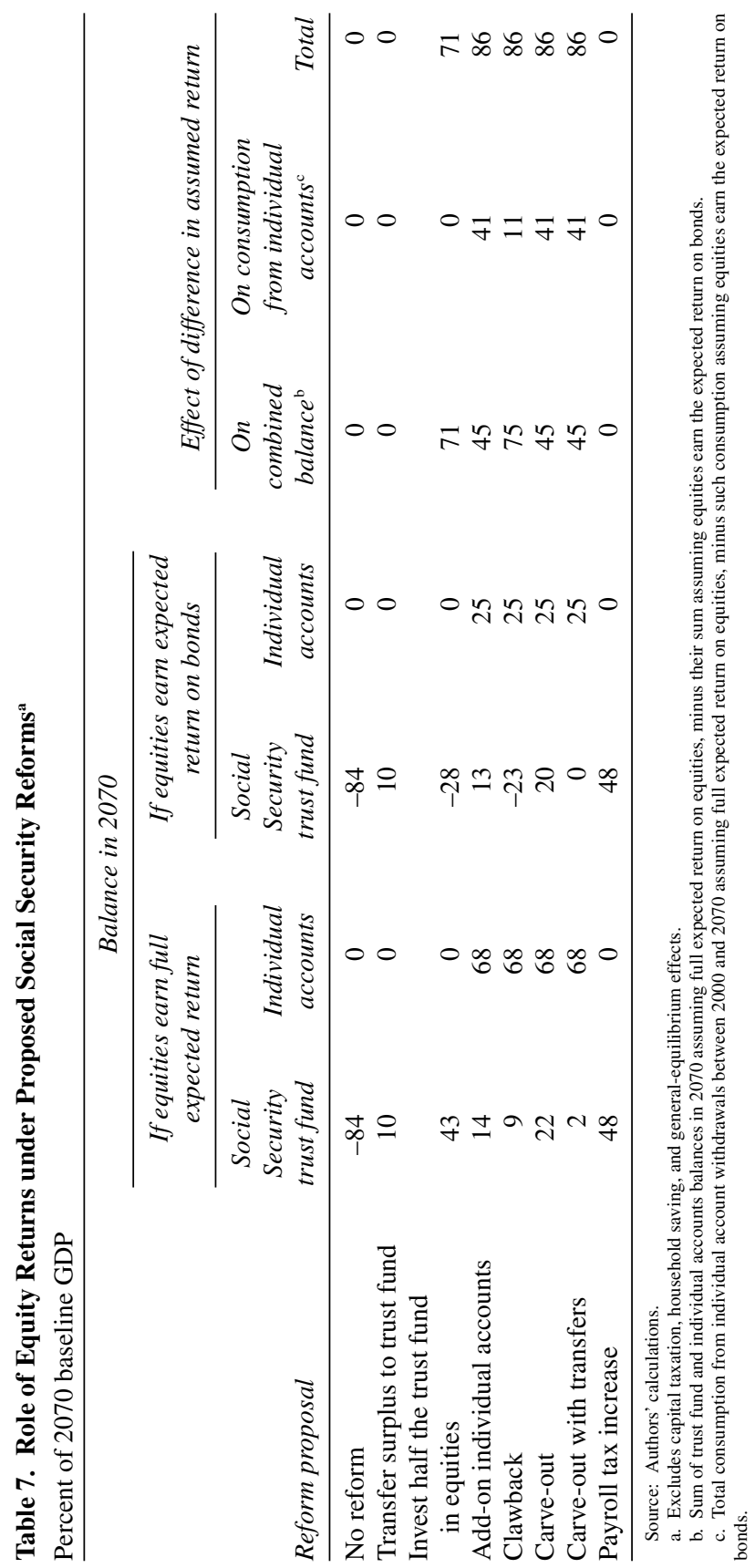


ual accounts (if any) - to finance given levels of benefits with a smaller up-front commitment of resources. We measure the importance of equity investments to each reform plan by calculating what would happen if equities earned only the bond rate of return. There are two basic effects: to the extent the retirement system has defined benefits, a lower return on equities reduces accumulated trust fund balances; to the extent the retirement system has defined contributions, a lower return on equities reduces retirement consumption. Thus, as noted above, the composition of benefits has a critical effect on the risk faced by beneficiaries and the government.

The first two columns of table 7 show total balances in the Social Security trust fund and individual accounts in 2070 assuming that equities earn their full expected return, and the next two columns show the same balances if equities earn only the expected return on bonds. The fifth column shows the difference in balances attributable to a higher equity return, summing the trust fund and the individual accounts. This difference is zero for the two plans that make no equity investments, but it is quite substantial for the other five plans. The sixth column shows the extra retirement consumption from individual accounts over the next seventy years that arises from holding equities rather than bonds in these accounts. ${ }^{80}$ This amount is zero for the two plans that rely entirely on traditional Social Security benefits; it is positive for the clawback plan, which pays small benefits from individual accounts; and it is much larger for the plans that rely more heavily on individual accounts. In the end, as the last column of the table shows, the total reliance on equity returns of the five plans that involve equities is roughly the same.

\section{Time Paths of Capital Accumulation}

Tables 5, 6, and 7 have shown the effect of reform in 2070, when benefit cuts are fully phased in and almost all retirees have had individual account contributions made on their behalf throughout their working lives. But the impact of reforms at earlier dates is important as well, for two reasons. First, incremental capital accumulation by 2040, say, gives us the best sense of how each reform plan changes feasible consumption for today's young workers. Second, the Social Security system has not yet

80. The annual amounts are accumulated forward to 2070 at the interest rate on bonds in the trust fund. 
been in existence for seventy years, and to assume that any current reform will remain in place for such a long period is probably unrealistic. Thus the short-run impact on capital accumulation may be as important a criterion for evaluating reform plans as the long-run impact.

Figure 2 shows the evolution of the capital stock corresponding to the reform plans and political economy rules in table 5. It is clear that much of the capital accumulation reported in table 5 occurs only after many years. Still, many of the plans increase the capital stock by 20 percent of GDP after two decades, which is a significant effect. The time profile of capital accumulation under plans with the same amount of ultimate accumulation is fairly similar. The main exception is the payroll tax increase, which is not implemented until 2015 but has important effects on saving (under two of the three political economy rules) in the very long run.

\section{Asymmetric, Partial Response to the Unified Budget Balance}

Our first three political economy rules assume either that there is no pressure for budget balance or that this pressure immediately balances the relevant budget concept (on a cyclically adjusted basis). It may be more realistic to assume that only part of any incipient budget surplus or deficit is offset immediately by changes in spending or taxes. Moreover, the response to surpluses may be quicker than the response to deficits, because tax cuts and spending increases are politically more palatable than tax increases and spending cuts.

Table 8 reports the effect of Social Security reform on saving under a political economy rule in which one-third of an incipient unified deficit is made up and two-thirds of an incipient unified surplus is dissipated ${ }^{81}$ The first column repeats the results from our unified budget rule in table 5; the second column shows results under this alternative unified budget rule with asymmetric, partial adjustment. The gradual and differential adjustment to surpluses and deficits has the largest effect on capital accumulation in the plans that invest half of the trust fund in equities, carve out individual accounts, or increase the payroll tax.

Equity investments by the trust fund depress capital formation by much less under this new political economy rule, for two reasons. First, although the equity returns continue to provide additional budget dollars for onbudget spending, the amount of this spending is muted by the partial

81. This formula is applied in each year of the analysis. 
Figure 2. Time Paths of Capital Accumulation under Alternative Political Economy Rules, 2000-70 ${ }^{\mathrm{a}}$

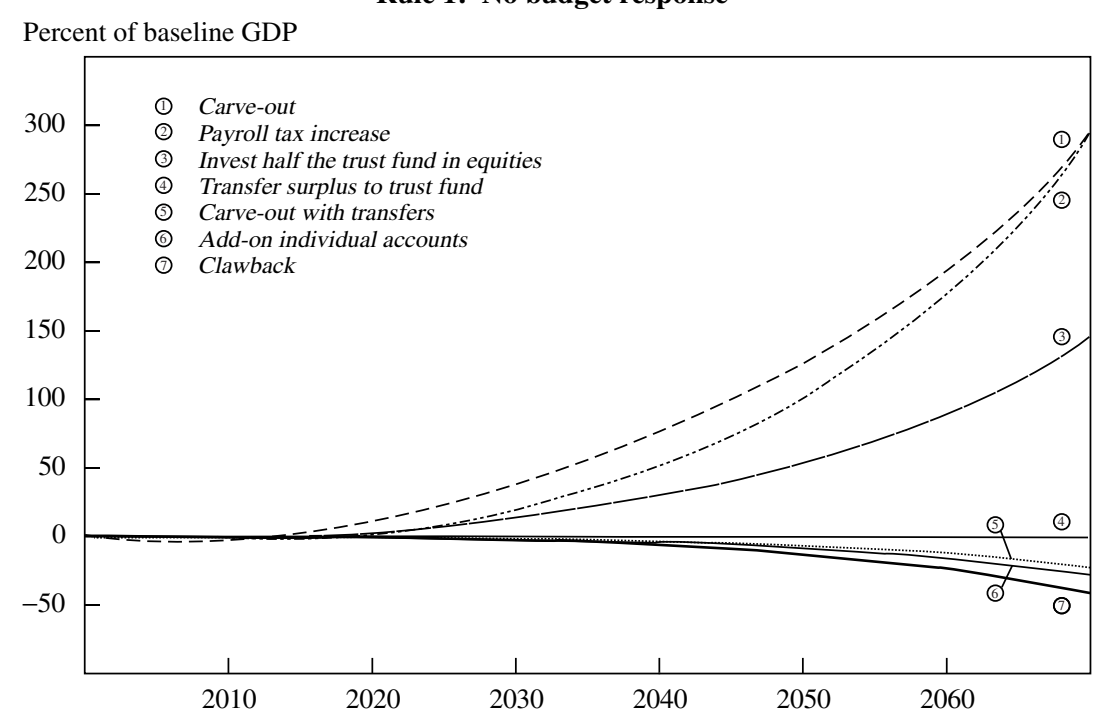

\section{Rule 1: No budget response}

Rule 2: Balance the unified budget

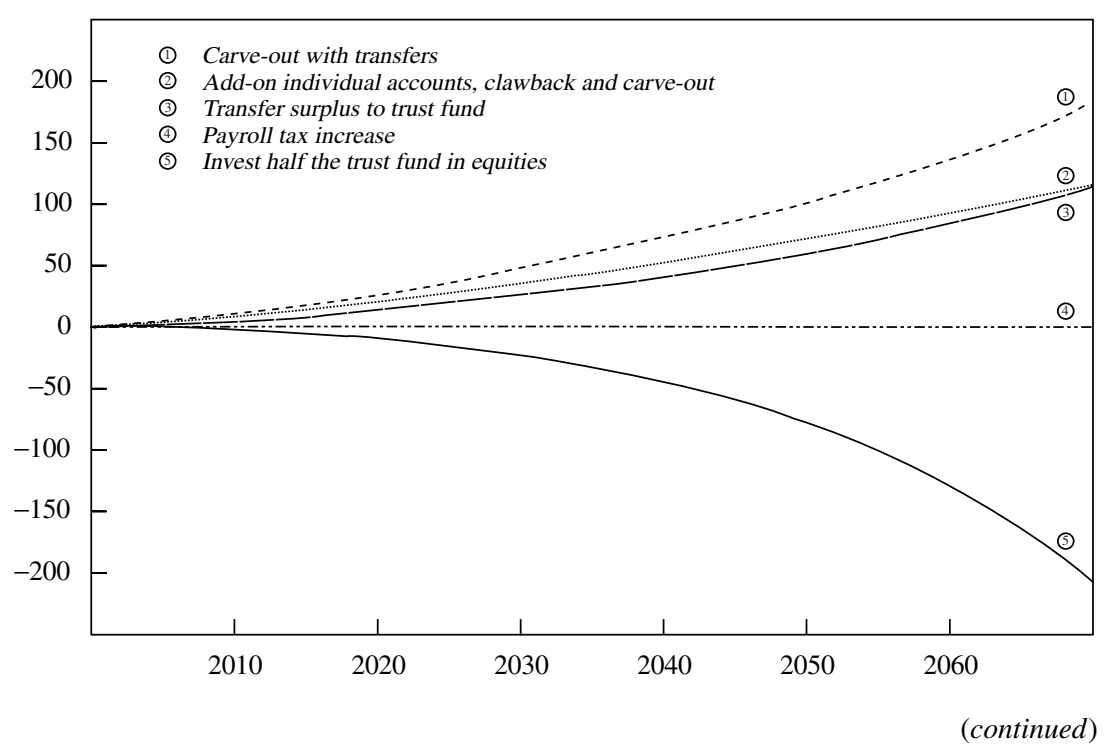


Figure 2. Time Paths of Capital Accumulation under Alternative Political Economy Rules, 2000-70' (continued)

Rule 3: Balance the on-budget account

Percent of baseline GDP

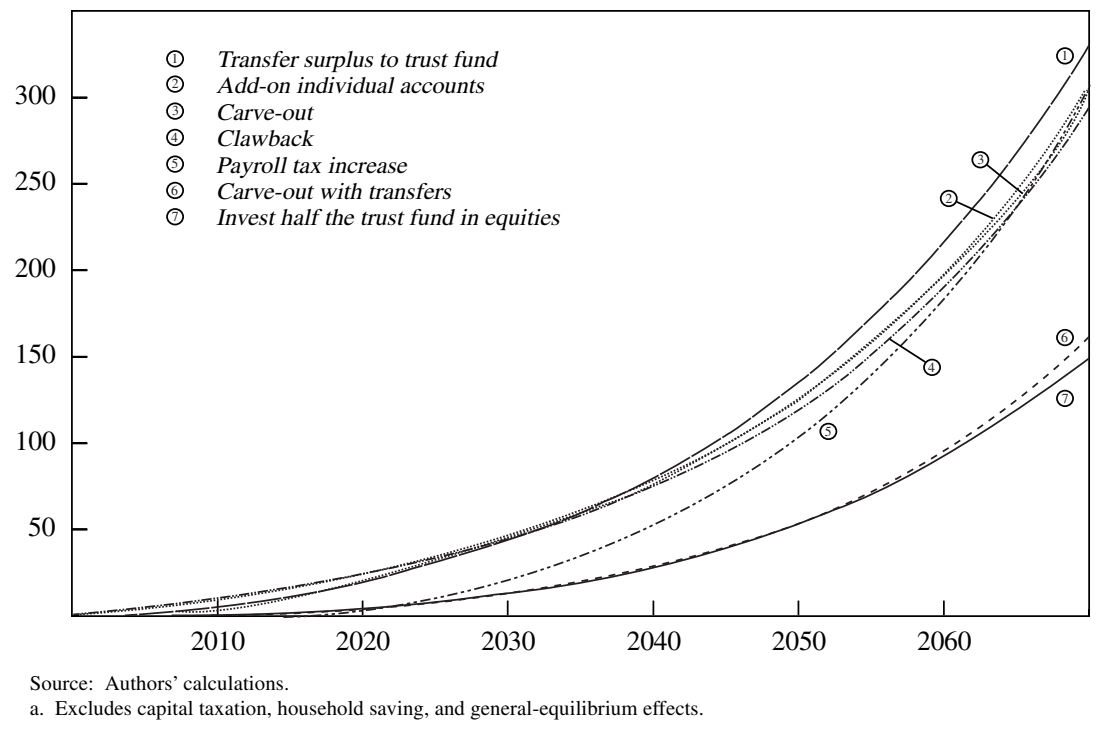

Table 8. Effects of Proposed Social Security Reforms on Capital Accumulation in 2070 with Asymmetric, Partial Budget Adjustment

Percent of 2070 baseline GDP

\begin{tabular}{lccc}
\hline & $\begin{array}{c}\text { Under } \\
\text { balanced } \\
\text { unified } \\
\text { budget rule }\end{array}$ & \multicolumn{2}{c}{$\begin{array}{c}\text { Under asymmetric, partial } \\
\text { adjustment rule }\end{array}$} \\
\cline { 3 - 4 } Reform proposal & $0(110)^{\mathrm{b}}$ & $\begin{array}{c}\text { OMB } \\
\text { baseline }\end{array}$ & $\begin{array}{c}\text { Pessimistic } \\
\text { baseline }\end{array}$ \\
\hline Transfer surplus to trust fund & & $0(97)$ & $0(76)$ \\
Invest half the trust fund & -207 & -124 & -62 \\
$\quad$ in equities & 111 & 108 & 82 \\
Add-on individual accounts & 111 & 103 & 76 \\
Clawback & 111 & 170 & 223 \\
Carve-out & $111(188)$ & $111(163)$ & $84(125)$ \\
Carve-out with transfers & 0 & 77 & 141 \\
Payroll tax increase & & &
\end{tabular}

\footnotetext{
Source: Authors' calculations.

a. From table 5 .

b. Numbers in parentheses are calculated using a special budget scoring rule whereby transfers of the surplus reduce resources available for other purposes.
} 
adjustment. Second, the benefit cuts now have a modest positive effect on capital accumulation, because they are not fully offset by additional on-budget spending. Funding of individual accounts crowds out on-budget spending, but this crowding out is less important to capital accumulation under the partial adjustment rule because it takes longer for any surplus to be eliminated. However, the cuts in traditional benefits that are part of these plans now have a positive impact on capital accumulation (whereas before they were ineffective), again because incipient surpluses are not completely offset by new spending. For three of the four individual account plans, these two effects roughly cancel. The exception is the carve-out plan, where deep benefit cuts strengthen the second effect and thereby boost capital accumulation substantially relative to the rule that immediately balances the unified budget. Finally, the payroll tax increase now has a substantial positive impact on saving, because the tax increases are only partially dissipated by new spending.

Because this political economy rule involves an asymmetric budget response, the amount of adjustment depends on whether the unified budget is in surplus or in deficit. Therefore, in contrast to what happens under our three main rules, changes in the baseline budget projection under this rule will alter the estimated impact of a plan on capital accumulation. To explore this effect, the third column of table 8 shows alternative estimates for this policy rule based on a more pessimistic budget baseline. In this scenario discretionary spending is held to a constant share of GDP, in contrast to the OMB baseline in which discretionary spending remains constant on an inflation-adjusted basis and therefore declines steadily as a share of GDP. Unified budget deficits emerge much more quickly in this scenario than in the base case, so that the one-third adjustment to a deficit (instead of the two-thirds adjustment to a surplus) applies for a greater share of the next seventy-five years. As a result, devoting on-budget resources to Social Security induces an offsetting decline in spending of only one-third rather than two-thirds, thereby reducing the impact on capital accumulation. In addition, plans that include benefit cuts are more effective in raising capital accumulation than before, since only one-third of the benefit cut is offset. Thus the two plans with transfers accomplish less capital accumulation than under the regular budget baseline, but plans with large benefit cuts or payroll tax increases (the plan that invests half of the trust fund in equities, the carve-out plan, and the payroll tax increase) lead to more incremental capital accumulation than before. 
Capital Taxes, Household Saving, and General-Equilibrium Effects

Table 9 incorporates the three factors-the capital taxation, household spending, and general-equilibrium responses-that were omitted from the basic results. For comparison purposes, the first column repeats the results from table 5 that showed additional capital accumulation in 2070 ignoring these responses.

The second column of the table adds the tax responses, which matter in two ways. First, our earlier calculations understated the return to saving by omitting corporate tax revenue. In the first panel of the table, in which political economy rule 1 is assumed, we see that incorporating this revenue increases incremental capital accumulation under each reform plan by about 20 percent. This first channel does not operate under the other two full-adjustment political economy rules, because those rules imply that additional spending dissipates any additional on-budget tax revenue.

Second, the personal income tax on capital income shifts part of the return to capital from households to the government. Under the first political economy rule, this shift has no effect on national saving because the income is saved in either sector. Under the second and third rules, however, the part of the capital return that is shifted to the government is dissipated, whereas the part that remains with households is saved. Because alternative reform plans leave households with portfolios of different compositions and therefore different capital tax burdens, the share of the capital return that is shifted to the government differs across plans. For example, investing half of the trust fund in equities increases household bond holdings relative to equity holdings; because bonds generate less tax revenue than do equities, this portfolio shift reduces personal income tax payments and boosts saving. Conversely, in reform plans that cause households to pay higher capital income taxes, this channel reduces capital accumulation. In both directions, however, the effects tend to be modest, typically resulting in changes of less than 10 percent.

The third column of table 9 incorporates household saving responses. Recall that we assume that household saving falls in response to funding of individual accounts, rises in response to cuts in traditional Social Security benefits, and falls when the budget surplus increases. Many reform plans would fund individual accounts while cutting traditional benefits; if such a switch left expected total retirement benefits unchanged, household 


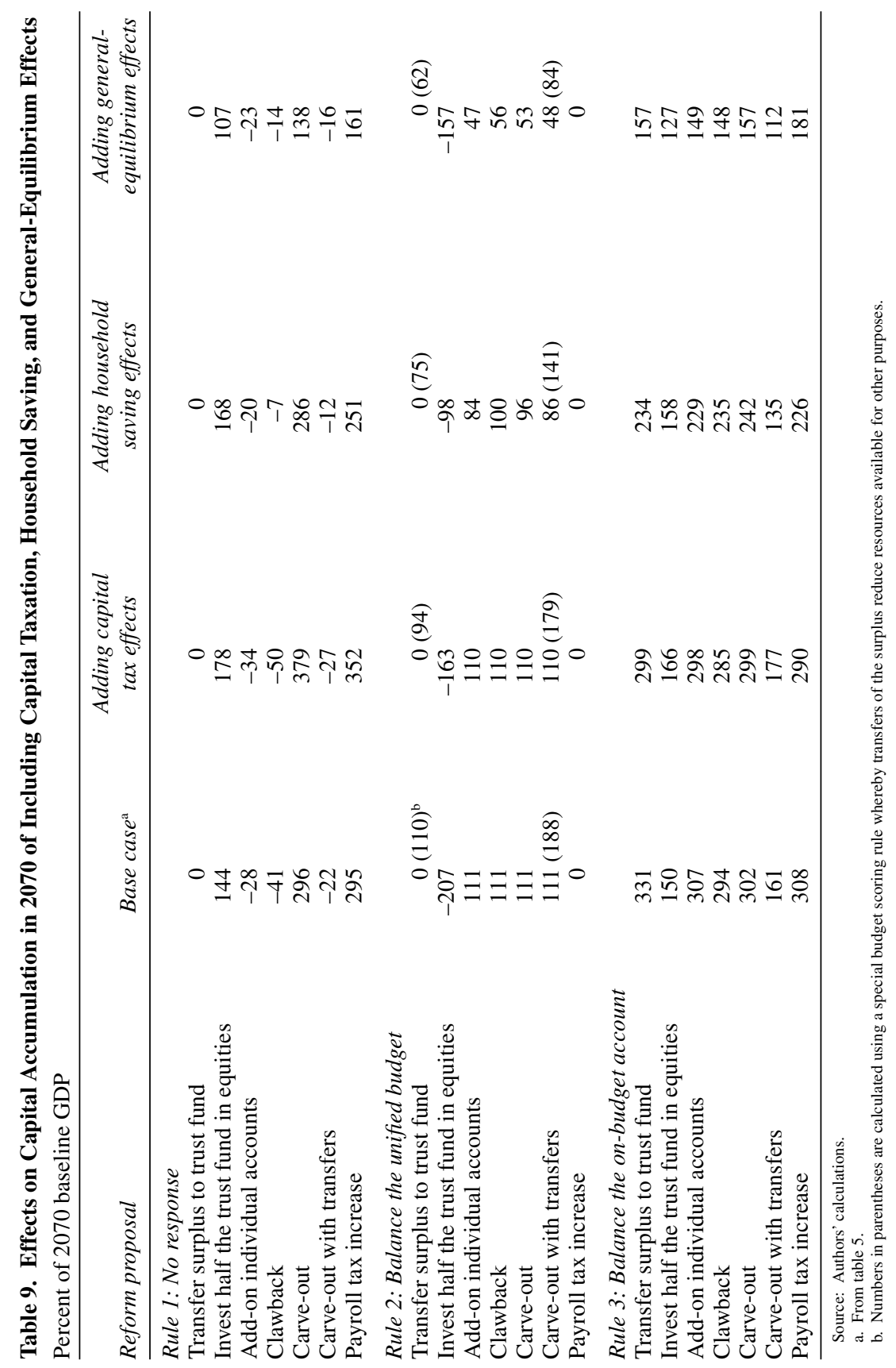


saving would fall slightly because we assume that individuals respond more to the funding of individual accounts than to benefit cuts. We begin in the middle panel, where the balanced unified budget rule neutralizes any effect of the budget balance on household saving. For the three basic individual account plans, the household saving response reduces capital accumulation a little. For the two plans with transfers to the Social Security trust fund, the special scoring rule would allow a unified budget surplus to be sustained, and households would respond to this surplus by reducing their saving, thus reducing total capital accumulation relative to the previous column. The large relative increase in capital accumulation (relative to the previous column) in the plan that invests half of the trust fund in equities occurs because households increase their saving in response to the benefit cut, and this is not offset by income from individual accounts. The third panel of the table shows that household saving effects reduce capital accumulation more when the political process balances the onbudget account rather than the unified budget. This occurs because balancing the on-budget account often generates unified surpluses that depress household saving.

The last column of table 9 adds general-equilibrium changes in the returns to capital and labor. The primary effect of these changes is to reduce the rate at which saving compounds in plans that increase capital accumulation and to increase the rate at which dissaving compounds in plans that decrease capital accumulation. This causes positive effects on capital accumulation to shrink substantially toward zero, with the degree of shrinkage determined by both the amount of accumulation and its timing. At the same time, negative effects on capital accumulation are now stronger than in the absence of general-equilibrium effects. ${ }^{82}$

\section{Conclusion}

The central lesson of this paper is that the effect of Social Security reform on national saving depends critically on the political economy of budget policy. If taxes and spending are adjusted to bring some measure of

82. We do not model additional household saving responses that might occur in response to changes in rates of return. If we did model such responses, both the positive and negative capital accumulation estimates would shrink toward zero. 
the budget into balance, any reform must set aside resources outside of that budget measure in order to achieve additional saving. Specifically, if the political process tends to balance the budget excluding Social Security, then saving is increased by plans that shift on-budget resources to either the Social Security trust fund or individual accounts, and by plans that cut Social Security benefits or increase payroll taxes. However, if the political process tends to balance the unified budget, then saving is increased by plans that shift resources to individual accounts, but not by plans that shift resources within the government or by proposals that change Social Security benefits or taxes.

The broader point is that budget accounting conventions help to frame decisions about spending and taxes-and that such framing matters crucially for the impact of Social Security reform on saving. It bears emphasizing that devoting additional resources to non-Social Security spending or tax cuts may be an appropriate goal of Social Security reform, but that goal conflicts to some extent with the often-stated goal of raising national saving to prepare for the aging of the population. 


\section{Comments and Discussion}

Matthew D. Shapiro: This ambitious paper has three major components. First, the authors model different proposals for changing Social Security within a single, unified framework. Second, they consider the effects of these changes under alternative "rules" for what happens in the rest of the budget. Third, they attempt to model the general-equilibrium response of the economy to these policy changes. Given the current focus of politicians, policymakers, and the public on both Social Security and the fiscal position of the government, this paper is very timely. Even putting aside the main theme of the paper-the role of the policy rules-the authors have done a service by comparing model reform proposals within a single framework. They also do a good job of clearing up some confusion over actual reform proposals by focusing on which aspects add to national saving and which do not.

To carry out this analysis, the authors need to make many assumptions. The outcome depends on the behavior of firms, households, and foreigners as well as on the policy rules that the government follows. Although it is not the focus of the analysis, the authors need to specify the behavior of private agents. The modeling perspective taken for these agents is similar to that for the government: the authors reduce their behavior to a set of parameters that express behavioral rules. For the government these parameters take on the value of zero or one; for example, the government saves all or none of the primary surplus. The rules for consumers are similarly cast, although the parameter values are not limited to zero or one. For example, consumers are assumed to treat some fraction of Social Security assets as net wealth. In departing from the frictionless, dynamic optimization framework, the authors have given themselves infinite degrees of 
freedom. One could devote an entire discussion to the specification and parameterization of these behavioral rules. Careful readers of this paper will be well aware that the behavioral rules might not be invariant to changes in policy rules. Moreover, the outcome of the analysis will depend on the choice of the behavioral parameters, given the rules. That said, my impression is that the authors have chosen reasonable parameter values. They have also explored how the choice of key parameters affects the analysis. Later I will suggest how this exploration could be made more systematic.

The authors analyze four alternative rules for the interaction of Social Security reforms with the rest of the federal budget:

- that there is no interaction,

- that the on-budget account is balanced,

- that the unified budget is balanced, or

- that the budget process tends toward on-budget balance but does so only partially in a given period and asymmetrically.

I think it is better to call these four possibilities "scenarios" rather than "rules." Although the mechanical playing out of accounting rules does have analogues in fiscal policy, for example in the various balanced-budget rules of state governments, it is not obvious that they are as helpful for understanding the federal government's behavior. Since the federal rules of the game are essentially period-by-period choices of the policy process, it may not be useful to think of one accounting concept or another as written in stone.

The appeal of the paper's scenario-based analysis depends on its time horizon. Over a medium-run horizon, this framing of the debate is likely to be important. Consider how the terms of the debate during the 2000 presidential election would have been different had Social Security been offbudget. I have no doubt that having Social Security off-budget would have constrained the candidates in their various proposals for taxes, spending, and Social Security. The authors' simulations make this point systematically and convincingly.

Most of their results, however, focus on the very long run. Here I am more skeptical. Over the long run, government behavior will adjust in ways that make static budgetary rules less relevant. For this kind of analysis I would suggest a model of government that more closely mimics that of the consumer. A natural benchmark is to suppose that the government solves a dynamic optimization problem subject to a present-value budget 
constraint. Departures from this benchmark can be analyzed in parallel with the consumer's problem. How much foresight does the government show? Over what horizon does it smooth tax rates? These government behaviors parallel the degree of liquidity constraint or myopia on the part of consumers. Does expenditure react endogenously to shocks to taxes? This government behavior perhaps parallels the endogeneity of the labor supply of consumers. Does the government have different propensities to spend from different pools of resources (in this case the on- and off-budget accounts)? This government behavior parallels the "mental accounting" sometimes ascribed to consumers. It is not obvious that constant underlying behavior along these lines leads to constant behavior with respect to the rules articulated in the paper. For example, a myopic government will respond asymmetrically to shocks. Behavior that considers mental accounting might depend on the balance in the account in addition to any shock to it.

Although it is beyond the scope of this paper to specify full models of consumer and government behavior, it is worth considering them for several reasons. First, it places some discipline on specifying the behavioral rules for both the government and private agents. Second, the behavior of the government is likely to correlate with that of the private sector. Consider a private sector populated by agents who lack foresight or who have mental accounts that alter their propensity to consume from different pools of funds. Such a private sector would seems less likely to elect a government or support institutions that optimize with respect to a present-value budget constraint than would a private sector populated by faultless optimizers. Constitutional provisions (such as state balanced-budget requirements or checks and balances at the federal level) are efforts to enforce a longer view on a political process and a public that tend toward shortsightedness. In any case, if a correlation between government behavior and individual behavior can be established, it would limit the range of cases the authors need to consider.

The authors provide little guidance on how to interpret the policy rules they consider. Are they a menu of choices for policymakers? Can these choices be made binding, especially for future policymakers? Or will the choice of rule (or its enforcement) shift as political and economic circumstances change?

The historical behavior of budget rules provides evidence on these questions. The federal experience has been mixed. The Gramm-Rudman 
proposal and its successors did not bring about fiscal balance. In contrast, the tight ceilings on federal discretionary spending during the Clinton administration played a role in getting the federal budget into balance in the 1990s. Yet as the fall 2000 legislative session makes clear, this fiscal discipline may be short-lived once budget surpluses materialize. As already noted, the tax and spending proposals of the presidential candidates this year were clearly wedded to budget accountancy. If Social Security were off budget, their proposals might have been different. It is less obvious, however, that the interaction of budget accountancy and political rhetoric that we saw in the campaign will have a substantial impact on policy outcomes.

Evidence across countries, across states, and across time within the United States provides some guidance about which of the authors' policy scenarios is the most likely. In an earlier issue of the Brookings Papers, Alberto Alesina, Roberto Perotti, and José Tavares have reported crosscountry evidence on fiscal adjustments. ${ }^{1}$ Although their concern was with curing a deficit rather than disposing of a surplus, perhaps the questions are not totally asymmetric. Alesina, Perotti, and Tavares found that most adjustments fail, but certain political conditions improve the prospects for success somewhat. Interestingly, they found that the right and the left are equally unsuccessful at achieving fiscal consolidation. They did find, however, that the form of the adjustment matters: for example, it is easier to raise indirect taxes than to cut expenditure. Although this is not surprising, it does support the present authors' message that we need to consider where in the budget changes will be made.

The evidence on state budget rules is perhaps more relevant, but mixed. Budget rules do matter, but they are not strictly enforced. James Poterba found that, even in states with strict balanced-budget rules, budgetary shocks are not fully offset by expenditure or tax adjustments. ${ }^{2}$ Hence, the zero-one parameterization of the first three rules in the present paper is not realistic. The fourth, partial adjustment rule is a major step in the direction of realism.

What has happened in the United States in the past? Does revenue burn a hole in the government's pocket, or can a long-run policy to save budget surpluses be put in place? Alan Auerbach found that about half of any 
federal budget surprise gets spent over the medium run. ${ }^{3}$ Hence the government appears to be something in between a permanent-income agent and a spendthrift. This evidence paints a picture similar to Poterba's crossstate evidence and again points toward the relevance of the present authors' partial adjustment rule.

A final issue is that of uncertainty. Two major types of uncertainty bear on the paper: uncertainty about parameters and uncertainty about shocks. The paper gives a flavor of the range of possible outcomes by presenting results for the four policy rules. What it does not do is assess which rule is more likely to prevail or, more realistically, what is the probability of a transition from one rule to another.

The current fiscal situation highlights the importance of this uncertainty in at least two ways. First, the political consensus in the second half of the 1990s shifted to favor budget balance. This process began with the Clinton administration's emphasis on fiscal consolidation in 1993 and continued throughout the decade. Second, U.S. economic performance has been unexpectedly strong. Both the political and the economic events of the 1990s had unexpected, favorable consequences for the federal surplus. It is easy to imagine scenarios that would reverse them. The paper leaves open how different budget rules would be expected to perform in response to shocks to the economy. It also leaves open the question of shocks to the rules themselves.

There is also substantial uncertainty about the behavioral parameters underlying the simulations. These include households' marginal propensity to consume from private wealth, the degree to which households integrate Social Security wealth with private wealth, and the degree to which increments to national saving are absorbed abroad. Certain demographic parameters that bear on Social Security are subject to uncertainty as well. Plausible variation in birth, death, migration, and fertility rates can have an enormous impact. ${ }^{4}$

Finally, the paper neglects the uncertainty of returns in the stock market. The expected return is highly variable, and this uncertainty cumulates over time; it does not average out. By neglecting this fact, and treating the average return on equities as fixed, some proponents of private investment of Social Security taxes have done a serious disservice to the

3. Auerbach (1994).

4. See Lee and Tuljapurkar (1998). 
public debate. The present authors are relatively innocent of this false invocation of the law of large numbers, because in their analysis assets are reshuffled rather than invested incrementally. Nonetheless, their failure to explicitly account for uncertainty is a lost opportunity to bring greater clarity to this issue.

In short, there is substantial uncertainty about almost every aspect of this paper: the budget rules, private behavior, demographics, aggregate economic performance, and asset returns. Let me suggest a framework for summarizing this uncertainty. The authors could specify probability distributions for the key parameters. They could then simulate their model for different values of the parameters. Finally, they could tabulate probability-weighted results from the simulation. Similarly, they could provide confidence intervals for the predictions of their model. None of this would add substantially to the complexity of the paper's calculations. But it would provide a useful summary of the implications of the model and an assessment of the uncertainty surrounding its predictions.

Stephen P. Zeldes: Understanding the effects of Social Security reform on national saving is important, because national saving is the primary way in which current generations increase the resources available in the future. This paper by Douglas Elmendorf and Jeffrey Liebman makes significant strides toward improving our understanding of the interactions between political economy rules and Social Security reforms. One can tell from reading the paper that both authors have hands-on experience with shaping government policy. Rather than content themselves with a long list of the possible effects of various policies, they work hard to derive concrete and sensible estimates of the magnitude of each effect. These estimates make the paper much more valuable.

The authors start with a careful documentation of the shift from big federal budget deficits to big surpluses. This is an excellent summary of recent budget history, although I am not sure how relevant it is to the rest of the paper. The paper then breaks down national saving into government saving (equal to the on-budget surplus plus Social Security saving) and private saving (equal to saving in individual retirement saving accounts plus other household saving) and looks at the reactions of each of these components to various possible Social Security reforms. Each of these reactions is important, but the one that is the least studied, and the one on which the paper sheds the most light, is the government saving response. 
John Geanakoplos, Olivia Mitchell, and I (GMZ) have categorized Social Security reforms along three key dimensions: creating individual (defined-contribution) accounts, prefunding Social Security, and diversifying Social Security funds, in particular by investing in equities. ${ }^{1}$ GMZ argue that these dimensions are completely separate from each other. We could create or refrain from creating individual accounts, with or without prefunding, and do either or both of these, or neither, with or without diversification. Because any of these combinations is feasible, the decision to move along any one dimension is in principle separable from the decision to move along any other. Although both the creation of individual accounts and diversification can influence national saving, they do so in subtle ways. The dimension that most directly influences national saving is prefunding: increasing prefunding will in general increase national saving.

GMZ ignored the reactions of government spending and taxes to Social Security reform proposals. In practice, however, the political economy issues that Elmendorf and Liebman examine may be very important and may create linkages among the three dimensions described by GMZ. For example, many proponents of individual accounts believe it would be difficult politically to build up a large Social Security trust fund, because such a buildup would induce Congress to increase on-budget spending, lower income taxes, raise Social Security benefits, or cut Social Security taxes. Any of these responses would offset the increase in national saving. This suggests that in order for prefunding to raise national saving, it must be done through the creation or expansion of individual accounts. Elmendorf and Liebman help us understand these arguments based on political economy.

The paper proposes and examines four rules characterizing the response of the on-budget balance to changes in the Social Security surplus. Under the first rule there is no pressure to balance the budget. When Social Security changes, Congress does not alter either taxes or spending. Under the second rule either on-budget spending or taxes respond to fully offset changes in the Social Security surplus, keeping the unified budget surplus at zero. Under the third rule the Social Security surplus is ignored, and instead the on-budget surplus adjusts to zero. Under the fourth rule the unified budget is balanced, as under the second rule, but surpluses are eliminated faster than deficits. 
For each political economy rule the paper carefully and systematically examines the effects of a variety of different Social Security reform plans on national saving. To explain what is underlying some of their results, I will focus on just two of these reform plans in somewhat simplified form. The first plan transfers general revenue (in practice about $\$ 3$ trillion, which I normalize to 100) to Social Security. Elmendorf and Liebman call this the "transfer surplus to trust fund" plan, but because it captures the essence of reform proposals by Vice President Al Gore, I will refer to it simply as plan G. The second plan I will consider transfers money (again 100 units) from general revenue into newly created individual accounts and cuts future Social Security benefits by 100 (in present value). The paper calls this the "carve-out with transfers" plan, but because it is consistent with ideas proposed by Texas governor George W. Bush, I label it plan B. In this simple setup, plans B and $\mathrm{G}$ are similar in that they both rely on general revenue transfers, but plan $G$ transfers the money into the trust fund, whereas plan B transfers it into individual accounts. To keep things simple, let us ignore all the individual and general-equilibrium responses and some of the more subtle features of the model and focus on the political responses-the paper's most important contribution.

Table 1 below describes how each of these two plans would affect government and national saving under each of the authors' first three budget rules. For each rule, the rows list the various saving measures-the onbudget surplus, Social Security saving, the unified budget surplus, individual account saving, and national saving — plus the unfunded liability of Social Security. This unfunded liability is the present value of all the promised future benefits that have accrued to date minus the current value of the trust fund. The unfunded liability of the current system has been estimated at about $\$ 9$ trillion.

Consider the first set of rows, the no-adjustment rule (rule 1). Plan G would cause the on-budget surplus to fall by 100 and the Social Security surplus to rise by 100 . There is no change in the unified surplus, because money is simply being shifted from one pot to another, and similarly there is no effect on national saving. Since 100 has been transferred into the trust fund, the unfunded liability goes down by 100 . Under plan B the onbudget surplus falls by 100 . There is no change in the Social Security surplus, but individual account saving rises by 100 . The unified surplus, therefore, goes down by 100 . 
Table 1. Effects of Alternative Social Security Reforms on Saving under Three Political Economy Rules

\begin{tabular}{|c|c|c|c|}
\hline \multirow[b]{2}{*}{ Item } & \multicolumn{3}{|c|}{ Change from baseline } \\
\hline & $G$ & $B$ & $B-G$ \\
\hline \multicolumn{4}{|l|}{ Rule 1: No adjustment } \\
\hline On-budget surplus & -100 & -100 & 0 \\
\hline Social Security surplus & 100 & 0 & -100 \\
\hline Unified budget surplus & 0 & -100 & -100 \\
\hline Individual account saving & 0 & 100 & 100 \\
\hline National saving & 0 & 0 & 0 \\
\hline Unfunded Social Security liability & -100 & -100 & 0 \\
\hline \multicolumn{4}{|l|}{ Rule 2: Balance unified budget } \\
\hline On-budget surplus & -100 & 0 & 100 \\
\hline Social Security surplus & 100 & 0 & -100 \\
\hline Unified budget surplus & 0 & 0 & 0 \\
\hline Individual account saving & 0 & 100 & 100 \\
\hline National saving & 0 & 100 & 100 \\
\hline Unfunded Social Security liability & -100 & -100 & 0 \\
\hline \multicolumn{4}{|l|}{ Rule 3: Balance on-budget account } \\
\hline On-budget surplus & 0 & 0 & 0 \\
\hline Social Security surplus & 100 & 0 & -100 \\
\hline Unified budget surplus & 100 & 0 & -100 \\
\hline Individual account saving & 0 & 100 & 100 \\
\hline National saving & 100 & 100 & 0 \\
\hline Unfunded Social Security liability & -100 & -100 & 0 \\
\hline
\end{tabular}

Comparing plans $\mathrm{B}$ and $\mathrm{G}$ (the difference, $\mathrm{B}-\mathrm{G}$, is reported in the third column), we see that under plan B the unified surplus is smaller, and individual account saving greater, than under plan G. National saving is unchanged under both plans, and the unfunded liability falls by the same amount in both plans. In other words, under this political economy rule, the two plans have identical effects on national saving and on the unfunded liability, and the only difference is that plan G generates a Social Security surplus and plan B an individual account surplus of the same magnitude. The difference boils down to who holds the extra funds, individuals or the trust fund.

Things get a little more interesting when we move to the political economy rule that balances the unified budget (rule 2). The results for plan $\mathrm{G}$ are the same as under budget rule 1: since there was no change in the uni- 
fied budget surplus in the first row, no adjustment is necessary. But under plan B the government was going to end up with a larger deficit or a smaller surplus than it otherwise would have. This means that Congress has to cut spending or raise taxes, bringing the unified budget surplus back to zero. As a result, plan B ends up with greater national saving, because it makes the measured unified surplus smaller, which causes a political reaction-Congress cuts spending or raises taxes-which in turn raises national saving. The unfunded liability of Social Security is identical under the two plans.

Under the political economy rule that balances the on-budget surplus (rule 3), both plans induce Congress to take action, because both cause a larger on-budget deficit or a smaller surplus. The same adjustment has to occur under both plans, so that the effects on national saving are identical.

Looking across all three sets of rows, we see that only under political economy rule 2 do the plans affect national saving differently. Again, this happens because, under this rule, plan B removes money from the unified budget surplus, which restrains Congress from cutting taxes or raising spending.

Two proposals have been made that would eliminate even this difference between plans B and G under rule 2. The first is to create a special, rather unusual scoring procedure for general revenue transfers that says that transferring 100 from general revenues into Social Security has a negative effect $(-100)$ on the unified budget surplus. Under this scoring procedure the unified surplus would change by the same amount under $G$ as under B, so Congress would react to the two plans in the same way. The second proposal is to alter plan $\mathrm{G}$ to include the purchase of 100 of equities by the trust fund and score this as an outlay. The effects of the modified plan $\mathrm{G}$ on congressional action and on national saving would be identical to those of B.

Let me next provide some comments on the paper's results and suggest some directions for future research. First, although the paper emphasizes the effects of Social Security reform on national saving, we need to remember that there are obviously other important criteria on which any reform should be judged. In fact, many reforms would cause national saving and consumer well-being to change in opposite directions, because households that are made better off by reform tend to increase their current spending, thus lowering national saving. In other words, many reforms that improve welfare actually end up lowering national saving. 
Second, the paper's title, in particular the phrase "in an Era of Budget Surpluses," is a bit misleading. This part of the title suggests, as does the first section of the paper, that the analysis is different under a baseline forecast of budget surpluses than it would be with a balanced budget or with projected deficits. Yet in most of the paper the authors examine symmetric rules, that is, rules that are independent of the level of the surplus. The fourth, asymmetric political economy rule is an important step in the right direction.

Third, future work in this area should improve the treatment of risk. This paper considers only expected present values, with no risk adjustment. Many other investigators, including the actuaries at the Social Security Administration, have followed the same approach, but it is one that I find problematic and that can give answers that are misleading and likely to be misinterpreted. ${ }^{2}$ The most important example of this relates to the treatment of the return on equities. The authors assume that the mean equity return is about 4 percentage points higher than the bond return, but they ignore the uncertainty of the equity return. This makes it difficult to interpret the results of plans that involve equity investments, either by the Social Security trust fund or through individual accounts. Adjusting for risk is not easy. One possible adjustment is to assume that the equity premium is exactly the compensation for risk, and therefore assume that the risk-adjusted stock and bond returns are identical. Although this is not completely satisfactory either, results based on this assumption (provided in the authors' table 7) do provide a useful alternative benchmark.

Fourth, I would like to suggest using the existing empirical evidence and conducting further empirical work to ascertain the political economy rule that best characterizes Congress. Such a response function would no doubt be more complicated than the simple rules presented in the paper. ${ }^{3}$ In particular, because the government likely responds not just to the current surplus but to accumulated past deficits and surpluses as well, the list of possible spending rules should be expanded to include rules based on the level of the debt. Henning Bohn, for example, examined how the U.S. primary surplus responds to changes in the debt-to-GDP ratio and found that, after adjusting for war and cyclical factors, the surplus tends to respond posi-

2. For further discussion of this point see Geanakoplos, Mitchell, and Zeldes (1999) and 1999 Technical Panel (1999).

3. See, for example, Bohn (1998) and Auerbach (2000). 
tively to the debt. ${ }^{4}$ That is, when the debt is large, Congress starts running a bigger surplus. That same methodology could be applied to examine how spending and taxes respond to the on-budget and the off-budget surpluses, as well as the on-budget and the off-budget (implicit) debt.

Finally, the paper might be a useful starting point for further work on the political risk inherent in Social Security. The paper points out that no consensus exists as to how current and future Congresses are likely to react to changes in the on-budget and the off-budget surpluses, and that this makes it difficult to forecast the effects on national saving. Nor is there agreement as to how future Social Security program rules governing contributions and benefits might be changed in response to large future imbalances in the system. In states of the world in which economic growth or mortality or other economic or demographic variables turn out to be different than forecast, Social Security might not be able to pay out promised benefits under current tax rates. Since the system does not have built-in adjustments for these contingencies, commissions get formed, politicians debate, the public discusses, and ultimately the rules are changed. But how Congress will ultimately change the rules is not predictable, and this introduces political risk into the system. As a first step toward designing a system with additional self-correcting features, it would be useful to examine how Congress has historically changed Social Security rules in response to surpluses or deficits within the Social Security system.

General discussion: Many panelists supported the view that political economy considerations are important in evaluating different Social Security proposals but expressed reservations about the authors' particular assumptions. For Gregory Mankiw the paper clarified how crucial one's view of political forces is for predicting the long-run consequences of proposals to reform Social Security. But he was skeptical that any particular accounting convention or arrangement - off-budget, on-budget, lockbox provisionswould endure over horizons as long as those considered by the authors. In Mankiw's view these concepts come and go with the political wind and economic circumstances. He suggested basing the analysis on deeper fundamentals, for example, assuming that political economic outcomes are determined by the median voter's preferences, with accounting conventions and other transitory features of the budgetary process following those preferences.

4. Bohn (1998). 
Christopher Sims agreed and suggested that it is important to think of more sophisticated political economy behavior than the authors considered. He believed the shift in the discussion from the "unified" budget to the "on" budget was not a random event, but rather reflected the fact that the aging population of baby-boomers is becoming an increasingly large fraction of the electorate. Sims believed that older people, who are known to be politically active, are well aware of the risk to the retirement system and they probably have little budgetary or accounting illusion. Their importance in the electorate and their intense interest in Social Security may be the primary reason why political discussions of Social Security have become more forward looking and why interest has grown in budgetary conventions that seem to protect the system. But the electorate fifty years down the road, when the baby-boomers have passed through the system, may have quite a different composition and quite different budgetary objectives. Sims concluded that how Social Security issues are framed in terms of budget accounting may be important, but only for much shorter horizons, such as the four-year election cycle, rather than the very long horizons considered by the authors.

In the same vein, David Wilcox worried about what will happen in the next recession when the pain involved in maintaining balance in the onbudget account might shift attention back to the unified surplus. This might be avoided if the discussion were shifted to a cyclically adjusted budget, but he wondered whether the complexity of that concept might be too great for it to survive in the political arena. James Duesenberry concurred with the view that the paper took too long a perspective. He suggested it would be useful for the authors to run the model over shorter time horizons, placing greater emphasis on the consequences of various policies over the next ten to twenty years.

Wilcox and William Gale agreed with the authors' view that the way budgetary issues are framed can have enormous effects on budgetary outcomes. Wilcox noted that moving the focus of the political conversation from the unified balance to the on-budget balance had changed the political debate from how to dispose of approximately $\$ 4.2$ trillion to how to dispose of approximately $\$ 2$ trillion. Gale added that the same principles that argue for taking Social Security off budget suggest that Medicare and government pensions should be off budget too. Taking these expenditures off budget would reduce the $\$ 2$ trillion on-budget surplus by another $\$ 800$ billion. 
Wilcox stressed the importance of simplicity in the real world. As one illustration of that point, he underscored how important it is for a politician to be able to declare his or her support for balancing something. For example, a politician would have found it much more politically salient, in the fiscal year just ended, to support the two-part goal of balancing the onbudget account and putting Social Security into long-term balance rather than the two-part goal of running a $\$ 230$ billion unified surplus and putting Social Security in long-term balance.

Gale observed that the experience of most countries that have engaged in reform of their retirement systems tends to confirm the importance of political economy considerations. In contrast to the standard economic model, which predicts that such reforms would result in higher national saving, workers typically have received tax cuts, and national saving has, if anything, diminished.

Robert Hall thought the paper and the discussion overemphasized the effect of Social Security reform on saving; these were effects that he thought the economics profession knew little about. He thought there should be greater attention to finding what method of operating the Social Security system yields the best path of individual benefits. He observed that Social Security as it is currently run is extraordinarily efficient. Mutual funds that people buy as individuals have operating costs that are typically twenty times as high. Employer-operated plans are similar: typically the employer pays a fee to the operator of the plan, and then each employee pays a significant management fee. Hall predicted that moving to individual accounts would involve a very substantial loss of efficiency, a prediction consistent with the experience of many countries that have privatized their retirement systems. Sims agreed that the focus on the effect of reforms on saving was too limited. He noted that an important literature, including the paper by George Hall and Stefan Krieger in this volume, argues that the central issue is how reforms affect the time path of taxes. In this analysis the essential feature of prefunding retirement programs is that it smooths distorting tax rates over time, whether or not it affects national saving. Mankiw emphasized the political risk that he believed was intrinsic in public systems. Some proposals for individual accounts, for example, are subject to the risk of clawbacks, which could be changed with the political climate. This led him to prefer individual accounts that are individually funded and vested. 


\section{References}

Aaron, Henry J., and Robert D. Reischauer. 1998. Countdown to Reform: The Great Social Security Debate. New York: Century Foundation Press.

Abel, Andrew B. 2000. "The Effects of Investing Social Security Funds in the Stock Market When Fixed Costs Prevent Some Households from Holding Stocks." Working Paper 7739. Cambridge, Mass.: National Bureau of Economic Research (June).

Alesina, Alberto, Roberto Perotti, and José Tavares. 1998. "The Political Economy of Fiscal Adjustments.” BPEA 1:1998, 197-248.

Archer, William, and E. Clay Shaw. 1999. "The Social Security Guarantee Plan: Saving and Strengthening Social Security without Raising Taxes or Cutting Benefits.” (Available at www.house.gov/archer/issues/social_security/details/ outline.html, April 7.)

Auerbach, Alan J. 1994. "The U.S. Fiscal Problem: Where We Are, How We Got Here, and Where Are We Going." In NBER Macroeconomics Annual, vol. 9, edited by Stanley Fischer and Julio Rotemberg. Cambridge, Mass.: National Bureau of Economic Research.

—. 1996. "Tax Reform, Capital Allocation, Efficiency, and Growth." In Economic Effects of Fundamental Tax Reform, edited by Henry J. Aaron and William G. Gale. Brookings.

2000. "Formation of Fiscal Policy: The Experience of the Past TwentyFive Years." Federal Reserve Bank of New York Economic Policy Review 6(1): 9-23.

Auerbach, Alan J., and William G. Gale. 2000. "Perspectives on the Budget Surplus.” Working Paper 7837. Cambridge, Mass.: National Bureau of Economic Research (August).

Auerbach, Alan J., Jagadeesh Gokhale, and Laurence J. Kotlikoff. 1991. "Generational Accounts: A Meaningful Alternative to Deficit Accounting." In Tax Policy and the Economy, vol. 5, edited by David Bradford. MIT Press.

Ball, Robert M. 1998. “Social Security Plus.” Unpublished paper. Alexandria, Va. (July).

Ball, Robert M., and others. 1997. "Social Security for the 21st Century: A Strategy to Maintain Benefits and Strengthen America's Family Protection Plan.” In Report of the 1994-1996 Advisory Council on Social Security. Washington.

Barro, Robert J. 1979. "On the Determination of the Public Debt.” Journal of Political Economy 87(5, part 1): 940-71.

Board of Trustees of the Federal Hospital Insurance Fund. 2000. 2000 Annual Report of the Board of Trustees of the Federal Hospital Insurance Fund. Washington: Health Care Financing Administration.

Board of Trustees of the Federal Old-Age and Survivors and Disability Insurance Trust Funds. 2000. The 2000 Annual Report of the Board of Trustees of the Fed- 
eral Old-Age and Survivors Insurance and Disability Insurance Trust Funds. Washington: Social Security Administration.

Bohn, Henning. 1998. "The Behavior of U.S. Public Debt and Deficits." Quarterly Journal of Economics 113(3): 949-63.

Bosworth, Barry, and Gary Burtless. 2000. "The Effects of Social Security Reform on Saving, Investment, and the Level and Distribution of Worker Well-Being." Unpublished paper. Chestnut Hill, Mass.: Center for Retirement Research at Boston College (January).

Bureau of Economic Analysis. 1997. "Fixed Reproducible Tangible Wealth in the United States: Revised Estimates for 1993-95 and Summary Estimates for 1925-96." Survey of Current Business 77(9): 37-47.

Congressional Budget Office. 1997a. "Long-Term Budgetary Pressures and Policy Options." Washington (March).

1997b. "An Economic Model for Long-Run Budget Simulations.” Washington (July).

. 1998. "Social Security and Private Saving: A Review of the Empirical Evidence.” Washington (July).

__ _ 1999. “The Long-Term Budget Outlook: An Update." Washington (December). (July).

Cutler, David M., and others. 1990. "An Aging Society: Opportunity or Challenge?" BPEA 1:1990, 1-56.

Diamond, Peter, and John Geanakoplos. 1999. "Social Security Investment in Equities I: Linear Case.” Working Paper 7103. Cambridge, Mass.: National Bureau of Economic Research (April).

Eisner, Robert. 1986. How Real Is the Federal Deficit? Free Press.

Elmendorf, Douglas W. 1996. "The Effect of Interest-Rate Changes on Household Saving and Consumption: A Survey.” Federal Reserve Board FEDS Working Paper 96-27 (June). Washington.

Elmendorf, Douglas W., and N. Gregory Mankiw. 1999. "Government Debt.” In Handbook of Macroeconomics, edited by John Taylor and Michael Woodford. Amsterdam: Elsevier Science.

Elmendorf, Douglas W., and Louise M. Sheiner. 2000. "Should America Save for Its Old Age? Fiscal Policy, Population Aging, and National Saving." Journal of Economic Perspectives 14(3): 57-74.

Engen, Eric M., and William G. Gale. 1997. "Effects of Social Security Reform on Private and National Saving." In Social Security Reform: Links to Saving, Investment, and Growth, edited by Steven A. Sass and Robert K. Triest. Boston: Federal Reserve Bank of Boston.

Engen, Eric M., William G. Gale, and John Karl Scholz. 1996. "The Illusory Effects of Saving Incentives on Saving." Journal of Economic Perspectives 10(4): 113-38. 
Feldstein, Martin. 1974. "Social Security, Induced Retirement, and Aggregate Capital Accumulation.” Journal of Political Economy 82(5): 905-26.

_ 1996. "The Missing Piece in Policy Analysis: Social Security Reform. The Richard T. Ely Lecture." American Economic Review 86(2): 1-14. 222-27.

Feldstein, Martin, and Philippe Bacchetta. 1991. "National Saving and International Investment." In National Saving and Economic Performance, edited by B. Douglas Bernheim and John B. Shoven. University of Chicago Press.

Feldstein, Martin, and Charles Horioka. 1980. "Domestic Savings and International Capital Flows.” Economic Journal 90(358): 314-29.

Feldstein, Martin, and Jeffrey Liebman. 2000. "The Distributional Effects of an Investment-Based Social Security System.” Working Paper 7492. Cambridge, Mass.: National Bureau of Economic Research (January).

Feldstein, Martin, Elena Ranguelova, and Andrew Samwick. 1999. “The Transition to Investment-Based Social Security when Portfolio Returns and Capital Profitability Are Uncertain.” Working Paper 7016. Cambridge, Mass.: National Bureau of Economic Research (March).

Feldstein, Martin, and Andrew Samwick. 1997. "The Economics of Prefunding Social Security and Medicare Benefits.” In NBER Macroeconomics Annual, edited by Ben Bernanke and Kenneth Rogoff. MIT Press.

— 1998. "Potential Effects of Two Percent Personal Retirement Accounts." Tax Notes 79(5): 615-20.

_. 2000. "Allocating Payroll Tax Revenue to Personal Retirement Accounts to Maintain Social Security Benefits and the Payroll Tax Rate.” Working Paper 7767. Cambridge, Mass.: National Bureau of Economic Research (June).

Geanakoplos, John, Olivia S. Mitchell, and Stephen P. Zeldes. 1998. "Would a Privatized Social Security System Really Pay a Higher Rate of Return?" In Framing the Social Security Debate: Values, Politics, and Economics, edited by R. Douglas Arnond, Michael J. Graetz, and Alicia H. Munnell. Brookings.

—. 1999. "Social Security Money’s Worth.” In Prospects for Social Security Reform, edited by Olivia S. Mitchell, Robert J. Meyers, and Howard Young. University of Pennsylvania Press.

Hines, James R., Jr. 1996. "Dividends and Profits: Some Unsubtle Foreign Influences.” Journal of Finance 51(2): 661-89.

Koitz, David Stuart. 1998. "Social Security and the Federal Budget: What Does Social Security’s Being 'Off Budget' Mean?” Report for Congress 98-422. Washington: Congressional Research Service.

Laibson, David I. 1997. "Golden Eggs and Hyperbolic Discounting.” Quarterly Journal of Economics 112(2): 443-77.

Lee, Ronald, and Shripad Tuljapurkar. 1998. "Uncertain Demographic Futures and Social Security Finances.” American Economic Review 88(2): 237-41. 
Lucas, Robert E., Jr. 1990. "Supply-Side Economics: An Analytic Review." Oxford Economic Papers 42(2): 293-316.

National Commission on Social Security Reform. 1983. Report of the National Commission on Social Security Reform. Washington: Government Printing Office.

1994-1996 Advisory Council on Social Security. 1997. Report of the 1994-1996 Advisory Council on Social Security. Washington.

1999 Technical Panel on Assumptions and Methods. 1999. Report to the Social Security Advisory Board. Washington.

Obstfeld, Maurice, and Kenneth Rogoff. 2000. "The Six Major Puzzles in International Macroeconomics: Is There a Common Cause?" In NBER Macroeconomics Annual, edited by Ben Bernanke and Kenneth Rogoff. Cambridge, Mass.: National Bureau of Economic Research.

Office of Management and Budget. 2000a. Budget of the United States Government, Fiscal Year 2001. Washington: Government Printing Office.

2000b. Mid-Session Review, Budget of the United States Government, Fiscal Year 2001. Washington: Government Printing Office.

Penner, Rudolph G. 1998. "Trust Fund Accounting and the Scoring Rules for Proposed Reforms of the Social Security System.” In Social Security Reform: Economic and Budget Concepts, Enforcement, and Scorekeeping Perspectives. Washington: Committee for a Responsible Federal Budget.

Perkins, Frances. 1946. The Roosevelt I Knew. Viking Press.

Poterba, James M. 1994. "State Responses to Fiscal Crises: The Effects of Budgetary Institutions and Politics." Journal of Political Economy 102(4): 799-821.

1998. "The Rate of Return to Corporate Capital and Factor Shares: New Estimates Using Revised National Income Accounts and Capital Stock Data.” Carnegie-Rochester Conference Series on Public Policy 48(1): 211-46.

Poterba, James M., Steven F. Venti, and David A. Wise. 1996. "How Retirement Savings Programs Increase Saving." Journal of Economic Perspectives 10(4): 91-112.

President's Commission on Budget Concepts. 1967. Report of the President's Commission on Budget Concepts. Washington: Government Printing Office.

Romer, Paul M. 1986. "Increasing Returns and Long-Run Growth.” Journal of Political Economy. 94(5): 1002-37.

Samwick, Andrew A. 2000. "Is Pension Reform Conducive to Higher Saving?" Review of Economics and Statistics 82(2): 264-72.

Skilling, David. 2000. "The Rise and Fall (and Rise Again?) of Public Debt." Unpublished paper. Harvard University (September). 
Smetters, Kent. 1998. "Privatizing versus Prefunding Social Security in a Stochastic Economy." CBO Technical Paper Series. Washington: Congressional Budget Office (August).

1999. "Arbitrage Pricing of Unfunded Benefit Guarantees: Rationale and Computations." Unpublished paper. University of Pennsylvania (January).

Thaler, Richard H., and H. M. Shefrin. 1981. "An Economic Theory of SelfControl." Journal of Political Economy. 89(2): 392-406.

U.S. Treasury Department. 2000. Monthly Treasury Statement of Receipts and Outlays of the United States Government. Department of the Treasury, Financial Management Service (September). 
